\title{
Synthesis and X-Ray Crystal Structure of $\alpha$-Keggin-Type Aluminum-Substituted Polyoxotungstate
}

\author{
Chika Nozaki Katoํ, Yuki Makino'ㅐ, Mikio Yamasaki², \\ Yusuke Kataoka ${ }^{3}$, Yasutaka Kitagawa ${ }^{3}$ and Mitsutaka Okumura ${ }^{3}$ \\ ${ }^{1}$ Shizuoka University \\ ${ }^{2}$ Rigaku Corporation \\ ${ }^{3}$ Osaka University \\ Japan
}

\section{Introduction}

Aluminum and its derivatives such as alloys, oxides, organometallics, and inorganic compounds have attracted considerable attention because of their extreme versatility and unique range of properties, including acidity, hardness, and electroconductivity (Cotton \& Wilkinson, 1988). Since the properties and activities of an aluminum species are strongly dependent on the structures of the aluminum sites, the syntheses of aluminum compounds with structurally well-defined aluminum sites are considerably significant for the development of novel and efficient aluminum-based materials. However, the use of these well-defined aluminum sites is slightly limited by the conditions resulting from the hydrolysis of the aluminum species by water (Djurdjevic et al., 2000; Baes \& Mesmer, 1976; Orvig, 1993; Akitt, 1989).

Polyoxometalates have been of particular interest in the fields of catalytic chemistry, surface science, and materials science because their chemical properties such as redox potentials, acidities, and solubilities in various media can be finely tuned by choosing appropriate constituent elements and countercations (Pope, 1983; Pope \& Müller, 1991, 1994). In particular, the coordination of metal ions to the vacant site(s) of lacunary polyoxometalates is one of the most effective techniques used for constructing efficient and well-defined active metal centers. Among various lacunary polyoxometalates, a series of Keggin-type phosphotungstates is one of the most useful types of lacunary polyoxometalates. Fig. 1 shows some examples of lacunary Keggin-type phosphotungstates, i.e., mono-lacunary a-Keggin [a-PW $\left.{ }_{11} \mathrm{O}_{39}\right]^{7-}$ (Contant, 1987), di-lacunary $\gamma$-Keggin $\left[\gamma-\mathrm{PW}_{10} \mathrm{O}_{36}\right]^{7-}$ (Domaille, 1990; Knoth, 1981), and tri-lacunary a-Keggin $\left[\mathrm{A}-\mathrm{\alpha}-\mathrm{PW}_{9} \mathrm{O}_{34}\right]^{9-}$ (Domaille, 1990) phosphotungstates. Knoth and co-workers first synthesized the Keggin derivative $\left(\mathrm{Bu}_{4} \mathrm{~N}\right)_{4}(\mathrm{H}) \mathrm{ClAlW}_{11} \mathrm{PO}_{39}$ by the reaction of mono-lacunary a-Keggin phosphotungstate with $\mathrm{AlCl}_{3}$ in dichloroethane (Knoth et al., 1983). However, only a few aluminum-coordinated polyoxometalates (determined by $\mathrm{X}$-ray crystallographic analysis) have been reported, e.g., a monomeric, $d i$-aluminum-substituted $\gamma$-Keggin polyoxometalate $\mathrm{TBA}_{3} \mathrm{H}\left[\gamma-\mathrm{SiW}_{10} \mathrm{O}_{36}\left\{\mathrm{Al}\left(\mathrm{OH}_{2}\right)\right\}_{2}(\mu-\right.$ 
$\left.\mathrm{OH})_{2}\right] \cdot 4 \mathrm{H}_{2} \mathrm{O}$ (TBA = tetra- $n$-butylammonium) (Kikukawa et al., 2008), a monomeric, monoaluminum-substituted a-Keggin polyoxometalate $\mathrm{K}_{6} \mathrm{H}_{3}\left[\mathrm{ZnW}_{11} \mathrm{O}_{40} \mathrm{Al}\right] \cdot 9.5 \mathrm{H}_{2} \mathrm{O}$ (Yang et al., 1997), and a dimeric aluminum complex having mono- and di-aluminum sites sandwiched by tri-lacunary a-Keggin polyoxometalate $\mathrm{K}_{6} \mathrm{Na}\left[\left(\mathrm{A}-\mathrm{PW}_{9} \mathrm{O}_{34}\right)_{2}\left\{\mathrm{~W}(\mathrm{OH})\left(\mathrm{OH}_{2}\right)\right\}\left\{\mathrm{Al}(\mathrm{OH})\left(\mathrm{OH}_{2}\right)\right\}\right.$ $\left.\left\{\mathrm{Al}(\mu-\mathrm{OH})\left(\mathrm{OH}_{2}\right)_{2}\right\}_{2}\right] \cdot 19 \mathrm{H}_{2} \mathrm{O}$ (Kato et al., 2010); these structures are shown in Fig. 2.
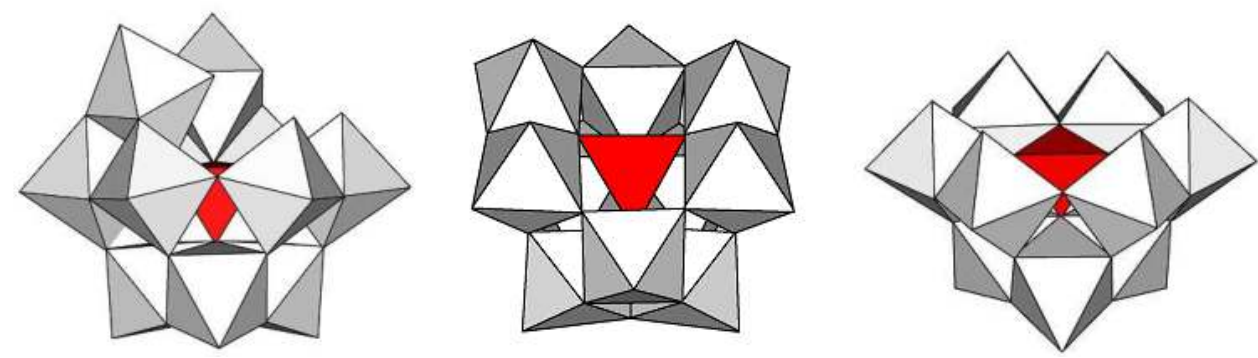

Fig. 1. Some examples of lacunary phosphotungstates. The polyhedral representations of mono-lacunary a-Keggin $\left[\mathrm{a}-\mathrm{PW}_{11} \mathrm{O}_{39}\right]^{7-}$ (left), di-lacunary $\gamma$-Keggin $\left[\gamma-\mathrm{PW}_{10} \mathrm{O}_{36}\right]^{7-}$ (center), and tri-lacunary a-Keggin $\left[\mathrm{A}-\mathrm{a}-\mathrm{PW}_{9} \mathrm{O}_{34}\right]^{9-}$ (right) phosphotungstates. The $\mathrm{WO}_{6}$ and internal $\mathrm{PO}_{4}$ groups are represented by the white octahedra and red tetrahedron, respectively.

In this study, we successfully obtained a monomeric, a-Keggin mono-aluminum-substituted polyoxotungstate in the form of crystals (suitable for X-ray structure analysis) of [ $n$ $\left.\left.\mathrm{C}_{4} \mathrm{H}_{9}\right)_{4} \mathrm{~N}\right]_{4}\left[\mathrm{a}-\mathrm{PW}_{11}\left\{\mathrm{Al}\left(\mathrm{OH}_{2}\right)\right\} \mathrm{O}_{39}\right]$ that were fully characterized by X-ray crystallography; elemental analysis; thermogravimetric/differential thermal analysis; Fourier transform infrared spectroscopy; and solution ${ }^{31} \mathrm{P},{ }^{27} \mathrm{Al}$, and ${ }^{183} \mathrm{~W}$ nuclear magnetic resonance spectroscopies. Although the X-ray crystallography of $\left[\mathrm{a}-\mathrm{PW} \mathrm{W}_{11}\left\{\mathrm{Al}\left(\mathrm{OH}_{2}\right)\right\} \mathrm{O}_{39}\right]^{4-}$ showed that the mono-aluminum-substituted site was not identified because of the high symmetry in the compound, the bonding mode (bond lengths and bond angles) were significantly influenced by the insertion of aluminum ions into the mono-vacant sites. In addition, density-functionaltheory (DFT) calculations showed a unique coordination sphere around the monoaluminum-substituted site in $\left[\mathrm{a}-\mathrm{PW}_{11}\left\{\mathrm{Al}\left(\mathrm{OH}_{2}\right)\right\} \mathrm{O}_{39}\right]^{4-;}$, this was consistent with the X-ray crystal structure and spectroscopic results. In this paper, we report the complete details of the synthesis, molecular structure, and characterization of $\left.\left[\left(n-\mathrm{C}_{4} \mathrm{H}\right)_{9}\right)_{4} \mathrm{~N}\right]_{4}\left[\mathrm{a}-\mathrm{PW}_{11}\right.$ $\left.\left\{\mathrm{Al}\left(\mathrm{OH}_{2}\right)\right\} \mathrm{O}_{39}\right]$.

\section{Experimental section}

\subsection{Materials}

$\mathrm{K}_{7}\left[\mathrm{a}-\mathrm{PW}_{11} \mathrm{O}_{39}\right] \cdot 11 \mathrm{H}_{2} \mathrm{O}$ (Contant, 1987) and $\mathrm{Cs}_{7}\left[\gamma_{\gamma}-\mathrm{PW}_{10} \mathrm{O}_{36}\right] \cdot 19 \mathrm{H}_{2} \mathrm{O}$ (Domaille, 1990; Knoth, 1981) were prepared as described in the literature. The number of solvated water molecules was determined by thermogravimetric/differential thermal analyses. Acetonitrile-soluble, tetra- $n$-butylammonium salts of $\left[a-\mathrm{PW}_{12} \mathrm{O}_{40}\right]^{3-}$ and $\left[\mathrm{a}-\mathrm{PW}_{11} \mathrm{O}_{39}\right]^{7-}$ were prepared by the addition of excess tetra- $n$-butylammonium bromide to the aqueous solutions of $\mathrm{Na}_{3}[\mathrm{a}-$ $\left.\mathrm{PW}_{12} \mathrm{O}_{40}\right] \cdot 16 \mathrm{H}_{2} \mathrm{O}$ (Rosenheim \& Jaenicke, 1917) and $\mathrm{K}_{7}\left[\mathrm{a}-\mathrm{PW}_{11} \mathrm{O}_{39}\right] \cdot 11 \mathrm{H}_{2} \mathrm{O}$. All the reagents and solvents were obtained and used as received from commercial sources. $\mathrm{Al}\left(\mathrm{NO}_{3}\right)_{3} \cdot 9 \mathrm{H}_{2} \mathrm{O}$ (Aldrich, 99.997\% purity) was used in the synthesis. The X-ray crystal structure of 
$\left[\left(\mathrm{CH}_{3}\right)_{2} \mathrm{NH}_{2}\right]_{4}\left[\mathrm{a}-\mathrm{PW}_{11} \mathrm{Re}^{V} \mathrm{O}_{40}\right]$ (Kato et al., 2010) was resolved by SHELXS-97 (direct methods) and re-refined by SHELXL-97 (Sheldrick, 2008). The crystal data are as follows: $\mathrm{C}_{8} \mathrm{H}_{32} \mathrm{~N}_{3} \mathrm{O}_{4} \mathrm{PReW}_{11}: M=3063.87$, trigonal, space group $R-3 m, a=16.53(2) \AA, c=25.21(4) \AA$, $V=5963(12) \AA^{3}, Z=6, D_{c}=5.119 \mathrm{~g} / \mathrm{cm}^{3}, R_{1}=0.0559(I>2 \sigma(I))$ and $w R_{2}=0.1513$ (for all data). The four dimethylammonium ions could not be identified due to the disorder (Nomiya et al., 2001, 2002; Weakley \& Finke, 1990; Lin et al., 1993). CCDC number 851154.

\subsection{Instrumentation/analytical procedures}

The elemental analysis was carried out by using Mikroanalytisches Labor Pascher (Remagen, Germany). The sample was dried overnight at room temperature under pressures of $10^{-3}-10^{-4}$ Torr before analysis. Infrared spectra were recorded on a Parkin Elmer Spectrum100 FT-IR spectrometer in $\mathrm{KBr}$ disks at room temperature. Thermogravimetric (TG) and differential thermal analyses (DTA) data were obtained using a Rigaku Thermo Plus 2 series TG/DTA TG 8120. TG/DTA measurements were performed in air by constantly increasing the temperature from 20 to $500{ }^{\circ} \mathrm{C}$ at a rate of $4{ }^{\circ} \mathrm{C}$ per min. The ${ }^{31} \mathrm{P}$ nuclear magnetic resonance (NMR) $(242.95 \mathrm{MHz})$ spectra in acetonitrile- $d_{3}$ solution were recorded in tubes (outer diameter: $5 \mathrm{~mm}$ ) on a JEOL ECA-600 NMR spectrometer. The 31P NMR spectra were referenced to an external standard of $85 \% \mathrm{H}_{3} \mathrm{PO}_{4}$ in a sealed capillary. Negative chemical shifts were reported on the $\delta$ scale for resonance upfields of $\mathrm{H}_{3} \mathrm{PO}_{4}(\delta 0)$. The ${ }^{27} \mathrm{Al}$ NMR $(156.36 \mathrm{MHz})$ spectrum in acetonitrile- $d_{3}$ was recorded in tubes (outer diameter: $5 \mathrm{~mm}$ ) on a JEOL ECA-600 NMR spectrometer. The ${ }^{27} \mathrm{Al}$ NMR spectrum was referenced to an external standard of saturated $\mathrm{AlCl}_{3}-\mathrm{D}_{2} \mathrm{O}$ solution (substitution method). Chemical shifts were reported as positive on the $\delta$ scale for resonance downfields of $\mathrm{AlCl}_{3}(\delta$ $0)$. The ${ }^{183} \mathrm{~W}$ NMR $(25.00 \mathrm{MHz})$ spectra were recorded in tubes (outer diameter: $10 \mathrm{~mm}$ ) on a JEOL ECA-600 NMR spectrometer. The ${ }^{183} \mathrm{~W}$ NMR spectra measured in acetonitrile- $d_{3}$ were referenced to an external standard of saturated $\mathrm{Na}_{2} \mathrm{WO}_{4}-\mathrm{D}_{2} \mathrm{O}$ solution (substitution method).
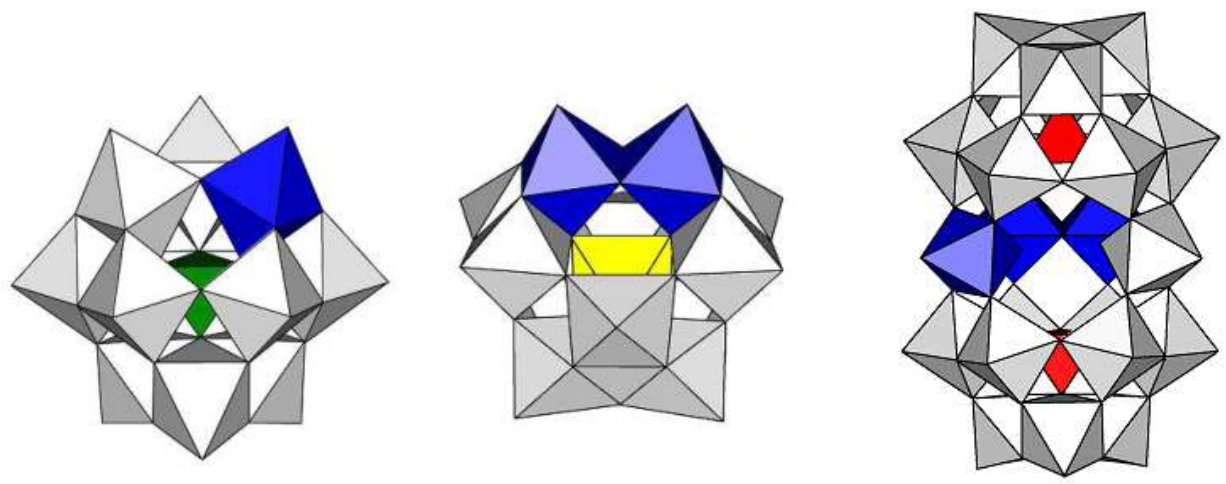

Fig. 2. The polyhedral representation of $\mathrm{K}_{6} \mathrm{H}_{3}\left[\mathrm{ZnW}_{11} \mathrm{O}_{40} \mathrm{Al}\right] \cdot 9.5 \mathrm{H}_{2} \mathrm{O}$ (left), $\mathrm{TBA} 3 \mathrm{H}\left[\gamma^{-} \mathrm{SiW}_{10^{-}}\right.$ $\left.\mathrm{O}_{36}\left\{\mathrm{Al}\left(\mathrm{OH}_{2}\right)\right\}_{2}(\mu-\mathrm{OH})_{2}\right] \cdot 4 \mathrm{H}_{2} \mathrm{O}$ (TBA = tetra- $n$-butylammonium) (center), and $\mathrm{K}_{6} \mathrm{Na}\left[\left(\mathrm{A}-\mathrm{PW}_{9^{-}}\right.\right.$ $\left.\left.\mathrm{O}_{34}\right)_{2}\left\{\mathrm{~W}(\mathrm{OH})\left(\mathrm{OH}_{2}\right)\right\}\left\{\mathrm{Al}(\mathrm{OH})\left(\mathrm{OH}_{2}\right)\right\}\left\{\mathrm{Al}(\mu-\mathrm{OH})\left(\mathrm{OH}_{2}\right)_{2}\right\}_{2}\right] \cdot 19 \mathrm{H}_{2} \mathrm{O}$ (right). The aluminum groups are represented by the blue octahedra. The $\mathrm{WO}_{6}$ groups are represented by white octahedra. The internal $\mathrm{ZnO}_{4}, \mathrm{SiO}_{4}$, and $\mathrm{PO}_{4}$ groups are represented by green, yellow, and red tetrahedra, respectively. 
Chemical shifts were reported as negative for resonance upfields of $\mathrm{Na}_{2} \mathrm{WO}_{4}(\delta 0)$. Potentiometric titration was carried out with $0.4 \mathrm{~mol} / \mathrm{L}$ tetra- $n$-butylammonium hydroxide as a titrant under argon atmosphere (Weiner et al., 1996). The compound $\left[\left(n-\mathrm{C}_{4} \mathrm{H}_{9}\right)_{4} \mathrm{~N}\right]_{4}[\mathrm{a}-$ $\left.\mathrm{PW}_{11}\left\{\mathrm{Al}\left(\mathrm{OH}_{2}\right)\right\} \mathrm{O}_{39}\right](0.018 \mathrm{mmol})$ was dissolved in acetonitrile $(30 \mathrm{~mL})$ at $25^{\circ} \mathrm{C}$ and the solution was stirred for approximately $5 \mathrm{~min}$. The titration data were obtained with a $\mathrm{pH}$ meter (Mettler Toledo). Data points were obtained in milivolt. A solution of tetra- $n$ butylammonium hydroxide $(9.0 \mathrm{mmol} / \mathrm{L})$ was syringed into the suspension in 0.25 equivalent intervals.

\subsection{Synthesis of $\left[\left(n-\mathrm{C}_{4} \mathrm{H}_{9}\right)_{4} \mathrm{~N}\right]_{4}\left[\alpha-\mathrm{PW}{ }_{11}\left\{\mathrm{Al}\left(\mathrm{OH}_{2}\right)\right\} \mathrm{O}_{39}\right]$}

$\mathrm{Cs}_{7}\left[\mathrm{\gamma}-\mathrm{PW}_{10} \mathrm{O}_{36}\right] \cdot 19 \mathrm{H}_{2} \mathrm{O}(2.00 \mathrm{~g} ; 0.538 \mathrm{mmol})$ was dissolved in water $(600 \mathrm{~mL})$ at $40{ }^{\circ} \mathrm{C}$, and solid $\mathrm{Al}\left(\mathrm{NO}_{3}\right)_{3} \cdot 9 \mathrm{H}_{2} \mathrm{O}(0.250 \mathrm{~g}, 0.666 \mathrm{mmol})$ was added to the colorless clear solution. After stirring for $1 \mathrm{~h}$ at $40{ }^{\circ} \mathrm{C}$, a solid $\left[\left(n-\mathrm{C}_{4} \mathrm{H}_{9}\right)_{4} \mathrm{~N}\right]_{4} \mathrm{Br}(12.14 \mathrm{~g} ; 37.7 \mathrm{mmol})$ was added to the solution, followed by stirring at $25{ }^{\circ} \mathrm{C}$ for 3 days. The white precipitate was collected on a glass frit (G4) and washed with water (ca. $1 \mathrm{~L}$ ). At this stage, a crude product was obtained in a $1.662 \mathrm{~g}$ yield. The crude product $(1.662 \mathrm{~g})$ was dissolved in acetonitrile $(10 \mathrm{~mL})$, followed by filtering through a folded filter paper (Whatman \#5). After the product was left standing for a week at $25^{\circ} \mathrm{C}$, colorless platelet crystals were formed. The obtained crystals weighted $0.752 \mathrm{~g}$ (the yield calculated considering that $\left[\mathrm{mol}\right.$ of $\left[\left(n-\mathrm{C}_{4} \mathrm{H}_{9}\right)_{4} \mathrm{~N}\right]_{4}[\mathrm{a}-$ $\left.\mathrm{PW}_{11}\left\{\mathrm{Al}\left(\mathrm{OH}_{2}\right)\right\} \mathrm{O}_{39}\right] /\left[\mathrm{mol}\right.$ of $\left.\mathrm{Cs}_{7}\left[\gamma_{-}-\mathrm{PW}_{10} \mathrm{O}_{36}\right] \cdot 19 \mathrm{H}_{2} \mathrm{O}\right] \times 100$ was $\left.36.9 \%\right)$. The elemental analysis results were as follows: $\mathrm{C}, 20.73 ; \mathrm{H}, 4.00 ; \mathrm{N}, 1.58 ; \mathrm{P}, 0.84 ; \mathrm{Al}, 0.77 ; \mathrm{W}, 54.6 ; \mathrm{Cs}$, $<0.1 \%$. The calculated values for $\left[\left(n-\mathrm{C}_{4} \mathrm{H}_{9}\right)_{4} \mathrm{~N}\right]_{4}\left[\mathrm{a}-\mathrm{PW}_{11}\left\{\mathrm{Al}\left(\mathrm{OH}_{2}\right)\right\} \mathrm{O}_{39}\right]=\mathrm{C}_{64} \mathrm{H}_{146} \mathrm{AlN}_{4} \mathrm{O}_{40} \mathrm{PW}_{11}$ : C, 20.82; H, 3.99; N, 1.52; P, 0.84; Al, 0.73; W, 54.77; Cs, $0 \%$. A weight loss of $2.16 \%$ was observed in the product during overnight drying at room temperature under $10^{-3}-10^{-4}$ Torr before the analysis, thereby suggesting the presence of two weakly solvated or adsorbed acetonitrile molecules $(2.18 \%)$. TG/DTA under atmospheric conditions showed a weight loss of $31.0 \%$ with an exothermic peak at $337^{\circ} \mathrm{C}$ was observed in the temperature range from 25 to $500{ }^{\circ} \mathrm{C}$; our calculations indicated the presence of four $\left[\left(\mathrm{C}_{4} \mathrm{H}_{9}\right)_{4} \mathrm{~N}\right]^{+}$ions, two acetonitrile molecules, and a water molecule (calcd. 28.4\%). The results were as follows: IR soectroscopy results (KBr disk): 1078s, 964s, 887s, 818s, 749m, 702w, 518w cm-1; 31P NMR $\left(25^{\circ} \mathrm{C}\right.$, acetonitrile- $\left.d_{3}\right): \delta-12.5 ;{ }^{27} \mathrm{Al} \mathrm{NMR}\left(25^{\circ} \mathrm{C}\right.$, acetonitrile- $\left.d_{3}\right): \delta 16.1 ; 183 \mathrm{~W}$ NMR $\left(25{ }^{\circ} \mathrm{C}\right.$, acetonitrile- $\left.d_{3}\right): \delta-56.2(2 \mathrm{~W}),-93.1(2 \mathrm{~W}),-108.6(2 \mathrm{~W}),-115.8(2 \mathrm{~W}),-118.5(1 \mathrm{~W}),-153.9(2 \mathrm{~W})$.

\subsection{X-Ray crystallography}

A colorless platelet crystal of $\left[\left(n-\mathrm{C}_{4} \mathrm{H}_{9}\right)_{4} \mathrm{~N}\right]_{4}\left[\mathrm{a}-\mathrm{PW} \mathrm{W}_{11}\left\{\mathrm{Al}\left(\mathrm{OH}_{2}\right)\right\} \mathrm{O}_{39}\right]\left(0.16 \times 0.16 \times 0.01 \mathrm{~mm}^{3}\right)$ was mounted on a MicroMount. All measurements were made on a Rigaku VariMax with a Saturn diffractometer using multi-layer mirror monochromated Mo Ka radiation $(\lambda=0.71075 \AA)$ at 93 K. Data were collected and processed using CrystalClear for Windows, and structural analysis was performed using the CrystalStructure for Windows. The structure was solved by SHELXS-97 (direct methods) and refined by SHELXL-97 (Sheldrick, 2008). Since one aluminum atom was disordering over twelve tungsten sites in [a-PW $\left.\mathrm{a}_{11}\left\{\mathrm{Al}\left(\mathrm{OH}_{2}\right)\right\} \mathrm{O}_{39}\right]^{4-}$, the occupancies for the aluminum and tungsten sites were fixed at $1 / 12$ and $11 / 12$ throughtout the refinement. Four tetra- $n$-butylammonium ions could not be modelled with disordered atoms. Accordingly, the residual electron density was removed using the SQUEEZE routine in PLATON (Spek, 2009). 


\subsection{Crystal data for $\left[\left(n-\mathrm{C}_{4} \mathrm{H}_{9}\right)_{4} \mathrm{~N}\right]_{4}\left[\mathrm{\alpha}-\mathrm{PW} \mathrm{W}_{11}\left\{\mathrm{Al}\left(\mathrm{OH}_{2}\right)\right\} \mathrm{O}_{39}\right]$}

$\mathrm{C}_{64} \mathrm{H}_{146} \mathrm{AlN}_{4} \mathrm{O}_{40} \mathrm{PW}_{11} ; \mathrm{M}=3692.17$, cubic, space group Im-3m (\#229), $a=17.665(2) \AA, V=$ $5512.2(8) \AA^{3}, Z=2, D_{c}=2.224 \mathrm{~g} / \mathrm{cm}^{3}, \mu(\mathrm{Mo}-\mathrm{Ka})=115.313 \mathrm{~cm}^{-1} \cdot R_{1}=0.0220(I>2 \sigma(I))$ and $w R_{2}=0.0554$ (for all data). GOF $=1.093$ (22662 total reflections, 652 unique reflections where $I>2 \sigma(I))$. CCDC number 851155.

\subsection{Computational details}

The optimal geometry of [a-PW $\left.\mathrm{PW}_{11}\left\{\mathrm{Al}\left(\mathrm{OH}_{2}\right)\right\} \mathrm{O}_{39}\right]^{4-}$ was computed by means of a DFT method. First, we optimized the crystal geometries and followed this up with single-point calculations with larger basis sets. All calculations were performed by a spin-restricted B3LYP on Gaussian09 program package (Frisch et al., 2009). The basis sets used for the geometry optimization were LANL2DZ for $W$ atoms, $6-31+G^{*}$ for $P$ atoms and $6-31 G^{*}$ for $H$, $\mathrm{O}$, and $\mathrm{Al}$ atoms. LANL2DZ and $6-31+\mathrm{G}^{*}$ were used for $\mathrm{W}$ and other atoms, respectively, for the single-point calculations. The geometry optimizations were started using the X-ray structure of $\left[\alpha-\mathrm{PW}_{12} \mathrm{O}_{40}\right]^{3-}$ as an initial geometry, and they were performed under the gas phase condition. The optimized geometries were confirmed to be true minima by frequency analyses. All atomic charges used in this text were obtained from Mulliken population analysis.

\section{Results and discussion}

\subsection{Synthesis and molecular formula of $\left[\left(n-\mathrm{C}_{4} \mathrm{H}_{9}\right)_{4} \mathrm{~N}\right]_{4}\left[\alpha-\mathrm{PW}_{11}\left\{\mathrm{Al}\left(\mathrm{OH}_{2}\right)\right\} \mathrm{O}_{39}\right]$}

The tetra- $n$-butylammonium salt of $\left[\mathrm{a}-\mathrm{PW}_{11}\left\{\mathrm{Al}\left(\mathrm{OH}_{2}\right)\right\} \mathrm{O}_{39}\right]^{4-}$ was formed by the direct reaction of aluminum nitrate with $\left[\gamma-\mathrm{PW}_{10} \mathrm{O}_{36}\right]^{7-}$ (the molar ratio of $\mathrm{Al}^{3+}:\left[\gamma-\mathrm{PW}_{10} \mathrm{O}_{36}\right]^{7-}$ was ca. 1.0) in an aqueous solution at $40{ }^{\circ} \mathrm{C}$ under air, followed by the addition of excess tetran-butylammonium bromide. The crystallization was performed by slow-evaporation from acetonitrile at $25{ }^{\circ} \mathrm{C}$. During the formation of $\left[\mathrm{a}-\mathrm{PW}_{11}\left\{\mathrm{Al}\left(\mathrm{OH}_{2}\right)\right\} \mathrm{O}_{39}\right]^{4-}$, the decomposition of a di-lacunary $\mathrm{\gamma}$-Keggin polyoxotungstate, and isomerization of $\mathrm{\gamma}$-isomer to a-isomer occurred in order to construct the mono-aluminum-substituted site in an a-Keggin structure. It was noted that the polyoxoanion $\left[a-\mathrm{PW}_{11}\left\{\mathrm{Al}\left(\mathrm{OH}_{2}\right)\right\} \mathrm{O}_{39}\right]^{4-}$ was easily obtained by the stoichiometric reaction of aluminum nitrate with a mono-lacunary a-Keggin polyoxotungstate, [a- $\left.\mathrm{PW}_{11} \mathrm{O}_{39}\right]^{7-}$, in an aqueous solution; however, a single species of [a-PW $\left.\mathrm{a}_{11}\left\{\mathrm{Al}\left(\mathrm{OH}_{2}\right)\right\}_{39}\right]^{4-}$ could not be obtained as a tetra- $n$-butylammonium salt by using $\left[\mathrm{a}-\mathrm{PW}_{11} \mathrm{O}_{39}\right]^{7-}$ as a starting polyoxoanion. ${ }^{1}$ Thus, single crystals that were suitable for $\mathrm{X}$ ray crystallography could be obtained for the crystallization of the tetra-nbutylammonium salt of $\left[\mathrm{a}-\mathrm{PW}_{11}\left\{\mathrm{Al}\left(\mathrm{OH}_{2}\right)\right\} \mathrm{O}_{39}\right]^{4-}$ synthesized by using a di-lacunary $\gamma^{-}$ Keggin polyoxotungstate.

\footnotetext{
${ }^{1}$ The ${ }^{31} \mathrm{P}$ NMR spectrum in acetonitrile- $d_{3}$ of the tetra- $n$-butylammonium salt of $\left[\mathrm{a}-\mathrm{PW}{ }_{11}\left\{\mathrm{Al}\left(\mathrm{OH}_{2}\right)\right\} \mathrm{O}_{39}\right]^{4-}$ prepared by the stoichiometic reaction of $\left[\mathrm{a}-\mathrm{PW}_{11} \mathrm{O}_{39}\right]^{7-}$ with $\mathrm{Al}\left(\mathrm{NO}_{3}\right)_{3} \cdot 9 \mathrm{H}_{2} \mathrm{O}$ in an aqueous solution showed two signals at $-12.35 \mathrm{ppm}$ and $-12.48 \mathrm{ppm}$. The signal at $-12.48 \mathrm{ppm}$ was assigned to the internal phosphorus atom in [a-PW $\left.\mathrm{PW}_{11}\left\{\mathrm{Al}\left(\mathrm{OH}_{2}\right)\right\} \mathrm{O}_{39}\right]^{4-}$, whereas the signal at $-12.35 \mathrm{ppm}$ could not be identified; however, the signal was not due to the proton isomer, as reported for $\left[\left(\mathrm{CH}_{3}\right)_{2} \mathrm{NH}_{2}\right]_{10}\left[\mathrm{Hf}\left(\mathrm{PW}_{11} \mathrm{O}_{39}\right)_{2}\right] \cdot 8 \mathrm{H}_{2} \mathrm{O}$ (Hou et al., 2007).
} 
The sample for the elemental analysis was dried overnight at room temperature under a vacuum of $10^{-3}-10^{-4}$ Torr. The elemental results for $\mathrm{C}, \mathrm{H}, \mathrm{N}, \mathrm{P}, \mathrm{Al}$, and $\mathrm{W}$ were in good agreement with the calculated values for the formula without any absorbed or solvated molecules for $\left[\left(n-\mathrm{C}_{4} \mathrm{H}_{9}\right)_{4} \mathrm{~N}\right]_{4}\left[\mathrm{a}-\mathrm{PW} \mathrm{W}_{11}\left\{\mathrm{Al}\left(\mathrm{OH}_{2}\right)\right\} \mathrm{O}_{39}\right]$.

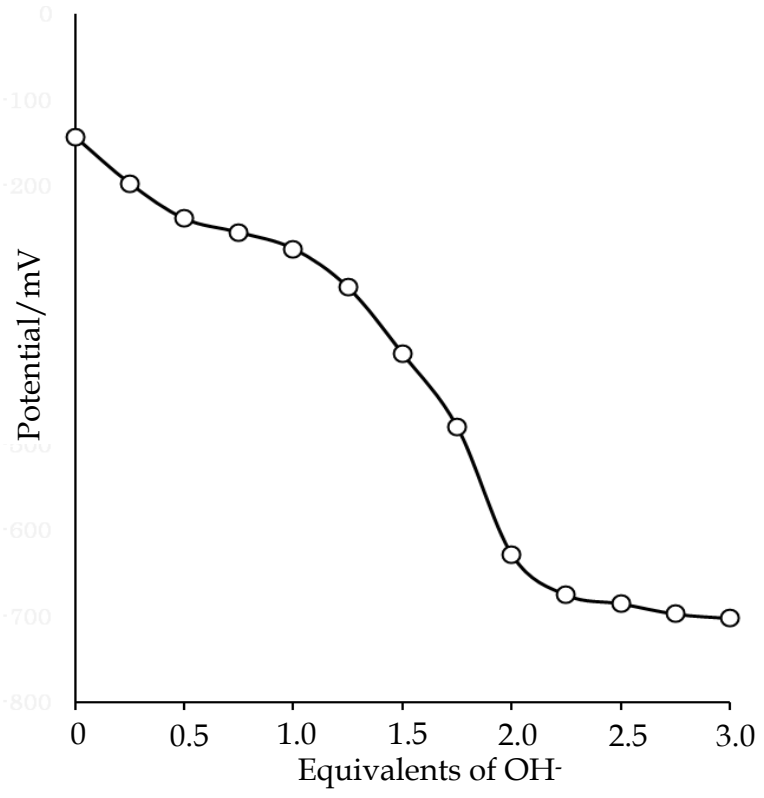

Fig. 3. Profile for the potentiometric titration of $\left[\left(n-\mathrm{C}_{4} \mathrm{H}_{9}\right)_{4} \mathrm{~N}\right]_{4}\left[\mathrm{a}-\mathrm{PW} \mathrm{W}_{11}\left\{\mathrm{Al}\left(\mathrm{OH}_{2}\right)\right\} \mathrm{O}_{39}\right]$ with tetra- $n$-butylammonium hydroxide as a titrant.

The Cs analysis revealed no contamination of cesium ions from $\mathrm{Cs}_{7}\left[\gamma-\mathrm{PW}_{10} \mathrm{O}_{36}\right] \cdot 19 \mathrm{H}_{2} \mathrm{O}$. The weight loss observed during the course of drying before the analysis was $2.16 \%$ for $[(n-$ $\left.\left.\mathrm{C}_{4} \mathrm{H}_{9}\right)_{4} \mathrm{~N}\right]_{4}\left[\mathrm{a}-\mathrm{PW}_{11}\left\{\mathrm{Al}\left(\mathrm{OH}_{2}\right)\right\} \mathrm{O}_{39}\right]$; this corresponded to two weakly solvated or adsorbed acetonitrile molecules. On the other hand, in the TG/DTA measurement performed under atmospheric conditions, a weight loss of $31.0 \%$ observed in the temperature range from 25 to $500{ }^{\circ} \mathrm{C}$ corresponded to four tetra- $n$-butylammonium ions, two acetonitrile molecules, and a water molecule.

From the potentiometric titration, a break point at 2.0 equivalents of added base was observed, as shown in Fig. 3. The titration profile revealed that $\left[\left(n-\mathrm{C}_{4} \mathrm{H}_{9}\right)_{4} \mathrm{~N}\right]_{4}[\mathrm{a}-$ $\left.\mathrm{PW}_{11}\left\{\mathrm{Al}\left(\mathrm{OH}_{2}\right)\right\} \mathrm{O}_{39}\right]$ had two titratable protons dissociated from the $\mathrm{Al}-\mathrm{OH}_{2}$ group. This result was consistent with the elemental analysis result. 


\subsection{The molecular structure of $\left[\left(n-\mathrm{C}_{4} \mathrm{H}_{9}\right)_{4} \mathrm{~N}\right]_{4}\left[\alpha-\mathrm{PW}_{11}\left\{\mathrm{Al}\left(\mathrm{OH}_{2}\right)\right\} \mathrm{O}_{39}\right]$}

The molecular structure of $\left[\mathrm{a}-\mathrm{PW}_{11}\left\{\mathrm{Al}\left(\mathrm{OH}_{2}\right)\right\} \mathrm{O}_{39}\right]^{4-}$ as determined by X-ray crystallography is shown in Figs. 4 and 5. The bond lengths and bond angles are summarized in appendix. The molecular structure of $\left[\mathrm{a}-\mathrm{PW}_{11}\left\{\mathrm{Al}\left(\mathrm{OH}_{2}\right)\right\} \mathrm{O}_{39}\right]^{4-}$ was identical to that of a monomeric, $\mathrm{a}-$ Keggin polyoxotungstate [a-PW $\left.\mathrm{P}_{12} \mathrm{O}_{40}\right]^{3-}$ (Neiwert et al., 2002; Busbongthong \& Ozeki, 2009). Due to the high symmetry space group, the eleven tungsten(VI) atoms were disordered and the mono-aluminum-substituted site was not identified, as observed for $\left[\mathrm{W}_{9} \mathrm{ReO}_{32}\right]^{5-}($ Ortéga et al., 1997), [a-PW $\left.\mathrm{PW}_{11} \mathrm{ReVO}_{40}\right]^{5-}$ (Kato et al., 2010), [\{SiW $\left.\mathrm{SiO}_{11} \mathrm{O}_{39} \mathrm{Cu}\left(\mathrm{H}_{2} \mathrm{O}\right)\right\}\left\{\mathrm{Cu}_{2}(\mathrm{ac})-\right.$ (phen $\left.\left.)_{2}\left(\mathrm{H}_{2} \mathrm{O}\right)\right\}\right]^{14-}($ phen $=$ phenanthroline, ac $=$ acetate) (Reinoso et al., 2006), $(\mathrm{ANIH})_{5}\left[\mathrm{PCu}\left(\mathrm{H}_{2} \mathrm{O}\right) \mathrm{W}_{11} \mathrm{O}_{39}\right](\mathrm{ANI}) \cdot 8 \mathrm{H}_{2} \mathrm{O}\left(\mathrm{ANI}=\right.$ aniline, $\mathrm{ANIH}^{+}=$anilinium ion) (Fukaya et al., 2011), $\mathrm{Cs}_{5}\left[\mathrm{PMn}\left(\mathrm{H}_{2} \mathrm{O}\right) \mathrm{W}_{11} \mathrm{O}_{39}\right] \cdot 4 \mathrm{H}_{2} \mathrm{O}$ (Patel et al., 2011), and $\mathrm{Cs}_{5}\left[\mathrm{PNi}\left(\mathrm{H}_{2} \mathrm{O}\right) \mathrm{W}_{11} \mathrm{O}_{39}\right] \cdot 2 \mathrm{H}_{2} \mathrm{O}$ (T. J. R. Weakley, 1987). However, the bond lengths of $\left[\left(n-\mathrm{C}_{4} \mathrm{H}_{9}\right)_{4} \mathrm{~N}\right]_{4}\left[\alpha-\mathrm{PW}_{11}\left\{\mathrm{Al}\left(\mathrm{OH}_{2}\right)\right\} \mathrm{O}_{39}\right]$ were clearly influenced by the insertion of aluminum ion into the vacant site as compared with those of $\left[\mathrm{CH}_{3} \mathrm{NH}_{3}\right]_{3}\left[\mathrm{PW}_{12} \mathrm{O}_{40}\right] \cdot 2 \mathrm{H}_{2} \mathrm{O},\left[\left(\mathrm{CH}_{3}\right)_{2} \mathrm{NH}_{2}\right]_{3}\left[\mathrm{PW}_{12} \mathrm{O}_{40}\right]$, and $\left[\left(\mathrm{CH}_{3}\right)_{3} \mathrm{NH}\right]_{3^{-}}$ $\left[\mathrm{PW}_{12} \mathrm{O}_{40}\right]$ (Busbongthong \& Ozeki, 2009) (Table 1). Thus, the lengths of the oxygen atoms belonging to the central $\mathrm{PO}_{4}$ tetrahedron $\left(\mathrm{O}_{\mathrm{a}}\right)$ are longer than those of the three alkylammonium salts of $\left[\mathrm{PW}_{12} \mathrm{O}_{40}\right]^{3-;}$ whereas, the lengths of the bridging oxygen atoms between corner-sharing $\mathrm{MO}_{6}(\mathrm{M}=\mathrm{W}$ and $\mathrm{Al})$ octahedra $\left(\mathrm{O}_{\mathrm{c}}\right)$ and bridging oxygen atoms between edge-sharing $\mathrm{MO}_{6}$ octahedra $\left(\mathrm{O}_{\mathrm{e}}\right)$ are shorter than those of $\left[\mathrm{PW}_{12} \mathrm{O}_{40}\right]^{3-}$. For comparisons, the bond lengths of mono-metal-substituted a-Keggin phosphotungstates, e.g., $\left[\left(\mathrm{CH}_{3}\right)_{2} \mathrm{NH}_{2}\right]_{4}\left[\mathrm{a}-\mathrm{PW}_{11} \mathrm{Re}^{\mathrm{V}} \mathrm{O}_{40}\right],(\mathrm{ANIH})_{5}\left[\mathrm{PCu}\left(\mathrm{H}_{2} \mathrm{O}\right) \mathrm{W}_{11} \mathrm{O}_{39}\right](\mathrm{ANI}) \cdot 8 \mathrm{H}_{2} \mathrm{O}$ (ANI $=$ aniline,

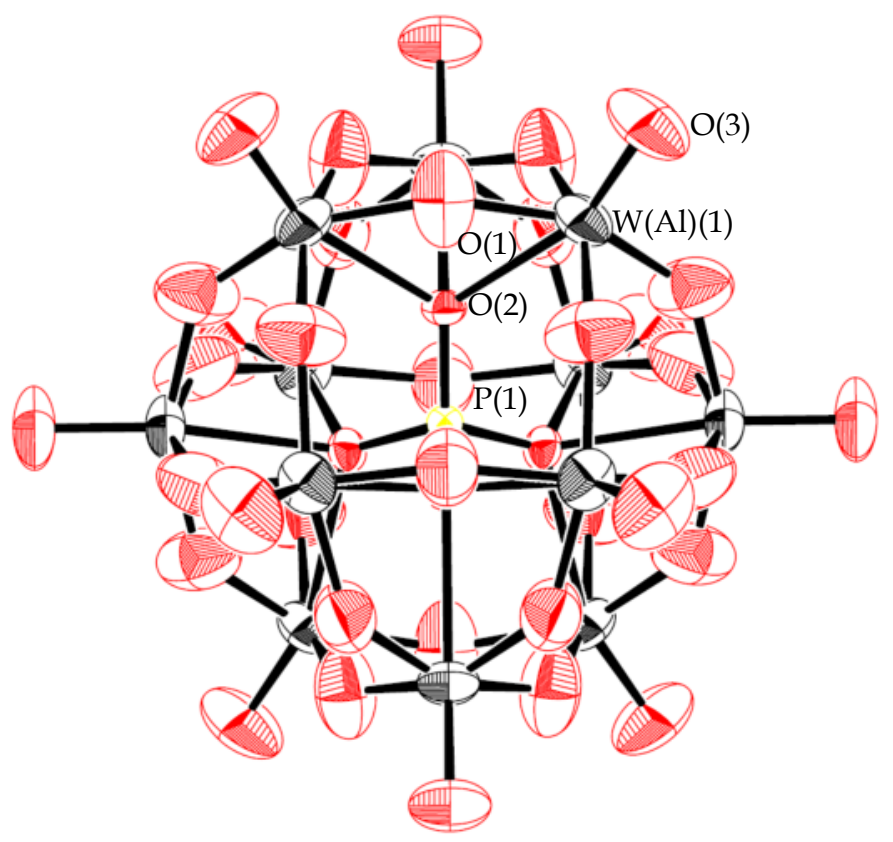

Fig. 4. The molecular structure (ORTEP drawing) of $\left[\mathrm{a}-\mathrm{PW} 11\left\{\mathrm{Al}\left(\mathrm{OH}_{2}\right)\right\} \mathrm{O}_{39}\right]^{4-}$. 


\begin{tabular}{|l|l|}
\hline & {$\left[\left(n-\mathrm{C}_{4} \mathrm{H}_{9}\right)_{4} \mathrm{~N}\right]_{4}\left[\mathrm{a}-\mathrm{PW}_{11}\left[\mathrm{Al}\left(\mathrm{OH}_{2}\right)\right\} \mathrm{O}_{39}\right]$} \\
\hline $\mathrm{W}(\mathrm{Al})-\mathrm{O}_{\mathrm{a}}$ & $2.466(2.466)$ \\
\hline $\mathrm{W}(\mathrm{Al})-\mathrm{O}_{\mathrm{c}}$ & $1.883(1.883)$ \\
\hline $\mathrm{W}(\mathrm{Al})-\mathrm{O}_{\mathrm{e}}$ & $1.883(1.883)$ \\
\hline $\mathrm{W}(\mathrm{Al})-\mathrm{O}_{\mathrm{t}}$ & $1.667(1.667)$ \\
\hline $\mathrm{P}-\mathrm{O}$ & $1.5206(1.5206)$ \\
\hline & {$\left[\mathrm{CH}_{3} \mathrm{NH}_{3}\right]_{3}\left[\mathrm{a}-\mathrm{PW}_{12} \mathrm{O}_{40}\right] \cdot 2 \mathrm{H}_{2} \mathrm{O}$} \\
\hline $\mathrm{W}-\mathrm{O}_{\mathrm{a}}$ & $2.4077-2.4606(2.4398)$ \\
\hline $\mathrm{W}-\mathrm{O}_{\mathrm{c}}$ & $1.8766-1.9407(1.9076)$ \\
\hline $\mathrm{W}-\mathrm{O}_{\mathrm{e}}$ & $1.8808-1.9448(1.9166)$ \\
\hline $\mathrm{W}-\mathrm{O}_{\mathrm{t}}$ & $1.6818-1.7068(1.6951)$ \\
\hline $\mathrm{P}-\mathrm{O}$ & $1.5286-1.5377(1.5324)$ \\
\hline & {$\left[\left(\mathrm{CH}_{3}\right)_{2} \mathrm{NH}\right]_{2}\left[\mathrm{a}-\mathrm{PW} \mathrm{W}_{12} \mathrm{O}_{40}\right]$} \\
\hline $\mathrm{W}-\mathrm{O}_{\mathrm{a}}$ & $2.4273-2.4568(2.4430)$ \\
\hline $\mathrm{W}-\mathrm{O}_{\mathrm{c}}$ & $1.9044-1.9164(1.9103)$ \\
\hline $\mathrm{W}-\mathrm{O}_{\mathrm{e}}$ & $1.9029-1.9234(1.9158)$ \\
\hline $\mathrm{W}-\mathrm{O}_{\mathrm{t}}$ & $1.7000-1.7038(1.7026)$ \\
\hline $\mathrm{P}-\mathrm{O}$ & $1.5220-1.5348(1.5313)$ \\
\hline & {$\left[\left(\mathrm{CH}_{3}\right)_{3} \mathrm{NH}\right]_{3}\left[\mathrm{a}-\mathrm{PW}_{12} \mathrm{O}_{40}\right]$} \\
\hline $\mathrm{W}-\mathrm{O}_{\mathrm{a}}$ & $2.4313-2.4497(2.4313)$ \\
\hline $\mathrm{W}-\mathrm{O}_{\mathrm{c}}$ & $1.8840-1.9286(1.9127)$ \\
\hline $\mathrm{W}-\mathrm{O}_{\mathrm{e}}$ & $1.8996-1.9437(1.9186)$ \\
\hline $\mathrm{W}-\mathrm{O}_{\mathrm{t}}$ & $1.6890-1.6970(1.6933)$ \\
\hline $\mathrm{P}-\mathrm{O}$ & $1.5296-1.5355(1.5340)$ \\
\hline
\end{tabular}

Table 1. Ranges and mean bond distances $(\AA)$ for $\left[\left(n-\mathrm{C}_{4} \mathrm{H}_{9}\right)_{4} \mathrm{~N}\right]_{4}\left[\mathrm{a}-\mathrm{PW} \mathrm{W}_{11}\left\{\mathrm{Al}\left(\mathrm{OH}_{2}\right)\right\}_{33}\right]$, and the three alkylammonium salts of $\left[\mathrm{PW}_{12} \mathrm{O}_{40}\right]^{3-}$. The terms $\mathrm{O}_{a}, \mathrm{O}_{c}, \mathrm{O}_{e}$, and $\mathrm{O}_{t}$ are explained in Fig. 5. The mean values are provided in parentheses.

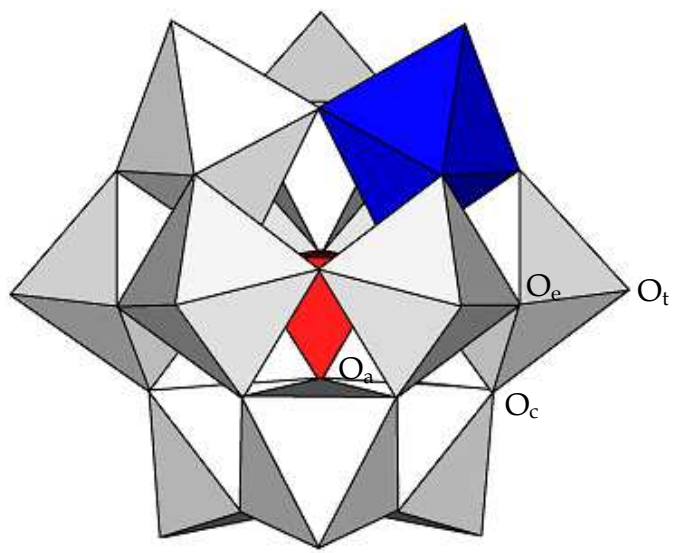

Fig. 5. The polyhedral representation of $\left[\mathrm{a}-\mathrm{PW}_{11}\left\{\mathrm{Al}\left(\mathrm{OH}_{2}\right)\right\} \mathrm{O}_{39}\right]^{4-}$. In the polyhedral representation, the $\mathrm{AlO}_{6}$ and $\mathrm{WO}_{6}$ groups are represented by blue and white octahedra, respectively. The internal $\mathrm{PO}_{4}$ group is represented by the red tetrahedron. Further, $\mathrm{O}_{a}$, 
oxygen atoms belonging to the central $\mathrm{PO}_{4}$ tetrahedron; $\mathrm{O}_{c}$, bridging oxygen atoms between corner-sharing $\mathrm{MO}_{6}(\mathrm{M}=\mathrm{Al}$ and $\mathrm{W})$ octahedra; $\mathrm{O}_{\mathrm{e}}$, bridging oxygen atoms between edgesharing $\mathrm{MO}_{6}$ octahedra $(\mathrm{M}=\mathrm{Al}$ and $\mathrm{W}) ; \mathrm{O}_{\mathrm{t}}$, terminal oxygen atoms.

$\mathrm{ANIH}^{+}=$anilinium ion), $\mathrm{Cs}_{5}\left[\mathrm{PMn}\left(\mathrm{H}_{2} \mathrm{O}\right) \mathrm{W}_{11} \mathrm{O}_{39}\right] \cdot 4 \mathrm{H}_{2} \mathrm{O}$, and $\mathrm{Cs}_{5}\left[\mathrm{PNi}\left(\mathrm{H}_{2} \mathrm{O}\right) \mathrm{W}_{11} \mathrm{O}_{39}\right] \cdot 2 \mathrm{H}_{2} \mathrm{O}$ as determined by X-ray crystallography are summarized in Table 2. Although a simple comparison was difficult to draw, the following trends were observed: The $\mathrm{W}-\mathrm{O}_{\mathrm{a}}$ bond lengths of $\left[\mathrm{PCu}\left(\mathrm{H}_{2} \mathrm{O}\right) \mathrm{W}_{11} \mathrm{O}_{39}\right]^{5-}, \quad\left[\mathrm{PMn}\left(\mathrm{H}_{2} \mathrm{O}\right) \mathrm{W}_{11} \mathrm{O}_{39}\right]^{5-}$, and $\left[\mathrm{PNi}\left(\mathrm{H}_{2} \mathrm{O}\right) \mathrm{W}_{11} \mathrm{O}_{39}\right]^{5-}$ were significantly longer than those of $\left[\mathrm{a}-\mathrm{PW}_{12} \mathrm{O}_{40}\right]^{3-}$ and $\left[\mathrm{a}-\mathrm{PW}_{11} \mathrm{ReV}^{\mathrm{V}} \mathrm{O}_{40}\right]^{4-}$, as observed for [a$\left.\mathrm{PW}_{11}\left\{\mathrm{Al}\left(\mathrm{OH}_{2}\right)\right\} \mathrm{O}_{39}\right]^{4-}$ due to the presence of a water molecule coordinated to the monometal-substituted sites. The $\mathrm{W}(\mathrm{M})-\mathrm{O}_{\mathrm{c}}$ and $\mathrm{W}(\mathrm{M})-\mathrm{O}_{\mathrm{e}}(\mathrm{M}=\mathrm{Re}, \mathrm{Cu}, \mathrm{Mn}$, and $\mathrm{Ni})$ bond lengths of the four polyoxoanions mentioned in Table 2 were similar to those of [a$\left.\mathrm{PW}_{12} \mathrm{O}_{40}\right]^{3-}$, whereas, the bond lengths of $\left[\alpha-\mathrm{PW}_{11}\left\{\mathrm{Al}\left(\mathrm{OH}_{2}\right)\right\} \mathrm{O}_{39}\right]^{4-}$ were clearly shorter than those of $\left[\mathrm{a}-\mathrm{PW}_{12} \mathrm{O}_{40}\right]^{3-}$.

\begin{tabular}{|c|c|}
\hline & {$\left[\left(\mathrm{CH}_{3}\right)_{2} \mathrm{NH}_{2}\right]_{4}\left[\alpha-\mathrm{PW}_{11} \mathrm{ReV}^{V} \mathrm{O}_{40}\right]$} \\
\hline $\mathrm{W}(\mathrm{Re})-\mathrm{O}_{\mathrm{a}}$ & $2.418-2.441(2.432)$ \\
\hline $\mathrm{W}(\mathrm{Re})-\mathrm{O}_{\mathrm{c}}$ & $1.896-1.914(1.906)$ \\
\hline $\mathrm{W}(\mathrm{Re})-\mathrm{O}_{\mathrm{e}}$ & $1.895-1.922(1.907)$ \\
\hline $\mathrm{W}(\mathrm{Re})-\mathrm{O}_{\mathrm{t}}$ & $1.647-1.694(1.680)$ \\
\hline \multirow[t]{2}{*}{$\mathrm{P}-\mathrm{O}$} & $1.538-1.540(1.539)$ \\
\hline & $(\mathrm{ANIH})_{5}\left[\mathrm{PCu}\left(\mathrm{H}_{2} \mathrm{O}\right) \mathrm{W}_{11} \mathrm{O}_{39}\right](\mathrm{ANI}) \cdot 8 \mathrm{H}_{2} \mathrm{O}$ \\
\hline $\mathrm{W}(\mathrm{Cu})-\mathrm{O}_{\mathrm{a}}$ & $2.4784-2.5044(2.4916)$ \\
\hline $\mathrm{W}(\mathrm{Cu})-\mathrm{O}_{\mathrm{c}}$ & $1.8946-1.9277(1.9077)$ \\
\hline $\mathrm{W}(\mathrm{Cu})-\mathrm{O}_{\mathrm{e}}$ & $1.8946-1.9277(1.9077)$ \\
\hline $\mathrm{W}(\mathrm{Cu})-\mathrm{O}_{\mathrm{t}}$ & $1.7163-1.7220(1.7178)$ \\
\hline \multirow{2}{*}{$\mathrm{P}-\mathrm{O}$} & $1.4925-1.5078(1.4965)$ \\
\hline & $\mathrm{Cs}_{5}\left[\mathrm{PMn}\left(\mathrm{H}_{2} \mathrm{O}\right) \mathrm{W}_{11} \mathrm{O}_{39}\right] \cdot 4 \mathrm{H}_{2} \mathrm{O}$ \\
\hline $\mathrm{W}(\mathrm{Mn})-\mathrm{O}_{\mathrm{a}}$ & $2.4220-2.5520(2.4874)$ \\
\hline $\mathrm{W}(\mathrm{Mn})-\mathrm{O}_{\mathrm{c}}$ & $1.9223-1.8698(1.9051)$ \\
\hline $\mathrm{W}(\mathrm{Mn})-\mathrm{O}_{\mathrm{e}}$ & $1.8689-1.9620(1.9079)$ \\
\hline $\mathrm{W}(\mathrm{Mn})-\mathrm{O}_{\mathrm{t}}$ & $1.6678-1.752(1.6889)$ \\
\hline \multirow[t]{2}{*}{$\mathrm{P}-\mathrm{O}$} & $1.4902-1.602(1.5265)$ \\
\hline & $\mathrm{Cs}_{5}\left[\mathrm{PNi}\left(\mathrm{H}_{2} \mathrm{O}\right) \mathrm{W}_{11} \mathrm{O}_{39}\right] \cdot 2 \mathrm{H}_{2} \mathrm{O}$ \\
\hline $\mathrm{W}(\mathrm{Ni})-\mathrm{O}_{\mathrm{a}}$ & $2.4013-2.5152(2.4792)$ \\
\hline $\mathrm{W}(\mathrm{Ni})-\mathrm{O}_{\mathrm{c}}$ & $1.8628-1.9430(1.8974)$ \\
\hline $\mathrm{W}(\mathrm{Ni})-\mathrm{O}_{\mathrm{e}}$ & $1.8633-1.9421(1.8964)$ \\
\hline $\mathrm{W}(\mathrm{Ni})-\mathrm{O}_{\mathrm{t}}$ & $1.6714-1.7354(1.7010)$ \\
\hline $\mathrm{P}-\mathrm{O}$ & $1.5150-1.5256(1.5209)$ \\
\hline
\end{tabular}

Table 2. Ranges and mean bond distances $(\AA)$ for four mono-metal-substituted a-Keggin phosphotungstates. The terms $\mathrm{O}_{a}$ and $\mathrm{O}_{t}$ are explained in Fig. 5. The terms $\mathrm{O}_{c}$ and $\mathrm{O}_{e}$ indicate bridging oxygen atoms between corner- and edge-sharing $\mathrm{MO}_{6}(\mathrm{M}=\mathrm{W}, \mathrm{Re}, \mathrm{Cu}$, $\mathrm{Mn}, \mathrm{Ni}$ ) octahedra. The mean values are provided in parentheses.

To investigate the coordination sphere around the mono-aluminum-substituted site in [a$\left.\mathrm{PW}_{11}\left\{\mathrm{Al}\left(\mathrm{OH}_{2}\right)\right\} \mathrm{O}_{39}\right]^{4-}$, the optimized geometry was computed by means of a DFT method, as 
shown in Figs. 6 and 7. The ranges and mean bond distances, and the Millken charges for the DFT-optimized [a-PW $\left.\mathrm{PW}_{11}\left\{\mathrm{Al}\left(\mathrm{OH}_{2}\right)\right\} \mathrm{O}_{39}\right]^{4-}$ are summarized in Tables 3 and 4 . It was noted that the mono-aluminum-substituted site was uniquely concave downward, which caused the extension of the P-O bond linkaged to the aluminum atom $(1.5654 \AA$ ) , whereas the Al-O bond linkaged to the internal phosphorus atom was shortened due to the insertion of the $\mathrm{Al}^{3+}$ ion that has a smaller ionic radius $(0.675 \AA)$ than that of $\mathrm{W}^{6+}(0.74 \AA)$ into the monovacant site (Shannon, 1976). The lengths of Al-O bonds at the corner- and edge-sharing Al$\mathrm{O}-\mathrm{W}$ bondings were shorter than those of $\mathrm{W}-\mathrm{O}$ bonds at the corner- and edge-sharing $\mathrm{W}-\mathrm{O}-$ $\mathrm{W}$ bondings, which caused shortening of the average $\mathrm{W}(\mathrm{Al})-\mathrm{O}$ bond lengths, as observed by X-ray crystallography.

The Mulliken charges of all oxygen atoms linkaged to aluminum atoms in $\left[\mathrm{a}-\mathrm{PW} \mathrm{W}_{11}\left\{\mathrm{Al}\left(\mathrm{OH}_{2}\right)\right\} \mathrm{O}_{39}\right]^{4-}$ were more positive than those linkaged to tungsten atoms in $\left[\mathrm{a}-\mathrm{PW}_{12} \mathrm{O}_{40}\right]^{3-}$; whereas the charges of oxygen atoms linkaged to tungsten atoms in $\left[\mathrm{a}-\mathrm{PW} \mathrm{W}_{11}\left\{\mathrm{Al}\left(\mathrm{OH}_{2}\right)\right\} \mathrm{O}_{39}\right]^{4-}$ were similar to those in $\left[\mathrm{a}-\mathrm{PW}_{12} \mathrm{O}_{40}\right]^{3-}$. In addition, the atomic charge of the phosphorus atom in $\left[a-\mathrm{PW}_{11}\left\{\mathrm{Al}\left(\mathrm{OH}_{2}\right)\right\} \mathrm{O}_{39}\right]^{4-}$ was more negative than that in $\left[\mathrm{a}-\mathrm{PW}_{12} \mathrm{O}_{40}\right]^{3-}$. In the case of mono-vanadium(V)-substituted Keggin silicotungstate $\left[\mathrm{SiW}_{11} \mathrm{VO}_{40}\right]^{5-}$, the net charge associated with the inner tetrahedron was very similar to that supported by $\mathrm{SiO}_{4}$ in $\left[\mathrm{SiW}_{12} \mathrm{O}_{40}\right]^{4-}$ (Maestre et al., 2001). Thus, the difference in the charge on the internal phosphorus atom for $\left[\mathrm{a}-\mathrm{PW} \mathrm{W}_{11}\left\{\mathrm{Al}\left(\mathrm{OH}_{2}\right)\right\} \mathrm{O}_{39}\right]^{4-}$ and $\left[\mathrm{a}-\mathrm{PW}_{12} \mathrm{O}_{40}\right]^{3-}$ might be due to the gravitation of aluminum atoms towards the internal $\mathrm{PO}_{4}$ group.

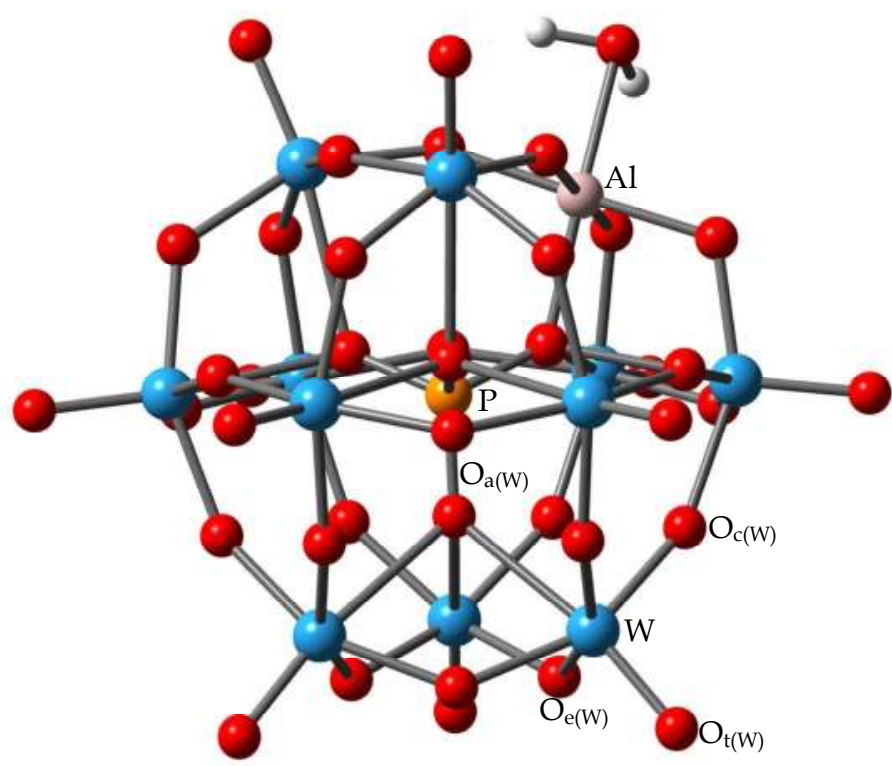

Fig. 6. The DFT-optimized geometry of $\left[\mathrm{a}-\mathrm{PW} \mathrm{P}_{11}\left\{\mathrm{Al}\left(\mathrm{OH}_{2}\right)\right\} \mathrm{O}_{39}\right]^{4-}$. The phosphorus, oxygen, aluminum, tungsten, and hydrogen atoms are represented by orange, red, pink, blue, and white balls, respectively. 


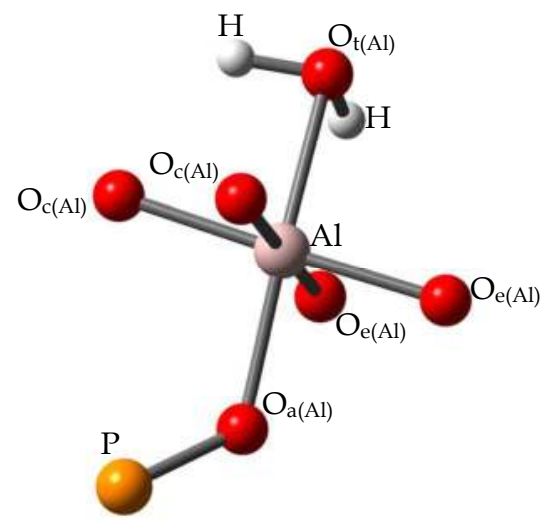

Fig. 7. The coordination sphere around the mono-aluminum-substituted site in DFToptimized [a-PW $\left.{ }_{11}\left\{\mathrm{Al}\left(\mathrm{OH}_{2}\right)\right\} \mathrm{O}_{39}\right]^{4-}$.

\begin{tabular}{|l|l|l|}
\hline & {$\left[\mathrm{a}-\mathrm{PW}_{11}\left\{\mathrm{Al}\left(\mathrm{OH}_{2}\right)\right]_{39}\right]^{4-}$} & {$\left[\mathrm{a}-\mathrm{PW}_{12} \mathrm{O}_{40}\right]^{--}$} \\
\hline $\mathrm{W}-\mathrm{O}_{\mathrm{a}}$ & $2.4422-2.5140(2.4702)$ & $2.4568-2.4579(2.4574)$ \\
\hline $\mathrm{W}-\mathrm{O}_{\mathrm{c}}$ & $1.8311-1.9828(1.9206)$ & $1.9202-1.9216(1.9209)$ \\
\hline $\mathrm{W}-\mathrm{O}_{\mathrm{e}}$ & $1.8373-1.9918(1.9267)$ & $1.9262-1.9276(1.9267)$ \\
\hline $\mathrm{W}-\mathrm{O}_{\mathrm{t}}$ & $1.7196-1.7246(1.7210)$ & $1.7103-1.7106(1.7105)$ \\
\hline $\mathrm{P}-\mathrm{O}$ & $1.5450-1.5654(1.5517)$ & $1.5530-1.5535(1.5533)$ \\
\hline $\mathrm{Al}-\mathrm{O}_{\mathrm{a}}$ & $1.9487(1.9487)$ & - \\
\hline $\mathrm{Al}-\mathrm{O}_{\mathrm{c}}$ & $1.8519,1.8955(1.8737)$ & - \\
\hline $\mathrm{Al}-\mathrm{O}_{\mathrm{e}}$ & $1.8723,1.9215(1.8969)$ & - \\
\hline $\mathrm{Al}-\mathrm{OH}_{2}$ & $2.0983(2.0983)$ & - \\
\hline
\end{tabular}

Table 3. Ranges and mean bond distances $(\AA)$ for $\left[\mathrm{a}-\mathrm{PW} \mathrm{P}_{11}\left\{\mathrm{Al}\left(\mathrm{OH}_{2}\right)\right\} \mathrm{O}_{39}\right]^{4-}$ and $\left[\mathrm{a}-\mathrm{PW}_{12} \mathrm{O}_{40}\right]^{3-}$ optimized by DFT calculations. The terms $\mathrm{O}_{a}, \mathrm{O}_{c}, \mathrm{O}_{e}$, and $\mathrm{O}_{\mathrm{t}}$ are explained in Fig. 5. The average values are provided in parentheses.

\begin{tabular}{|l|l|l|}
\hline & {$\left[\mathrm{a}-\mathrm{PW}_{11}\left\{\mathrm{Al}\left(\mathrm{OH}_{2}\right)\right\}_{399}\right]^{--}$} & {$\left[\mathrm{a}-\mathrm{PW}_{12} \mathrm{O}_{40}\right]^{--}$} \\
\hline $\mathrm{O}_{\mathrm{a}(\mathrm{W})}$ & $-0.7356--0.8445(-0.7734)$ & $-0.8951--0.8990(-0.8968)$ \\
\hline $\mathrm{O}_{\mathrm{c}(\mathrm{W})}$ & $-1.226--1.345(-1.317)$ & $-1.353--1.355(-1.353)$ \\
\hline $\mathrm{O}_{\mathrm{e}(\mathrm{W})}$ & $-1.030--1.160(-1.074)$ & $-1.085--1.087(-1.086)$ \\
\hline $\mathrm{O}_{\mathrm{t}(\mathrm{W})}$ & $-0.6757--0.6991(-0.6882)$ & $-0.6273--0.6277(-0.6275)$ \\
\hline $\mathrm{P}$ & $7.255(7.255)$ & $9.256(9.256)$ \\
\hline $\mathrm{W}$ & $2.101-2.343(2.257)$ & $2.343-2.346(2.345)$ \\
\hline $\mathrm{O}_{\mathrm{a}(\mathrm{Al})}$ & $-0.1495(-0.1495)$ & - \\
\hline $\mathrm{O}_{\mathrm{c}(\mathrm{Al})}$ & $-0.3332,-0.5920(-0.4626)$ & - \\
\hline $\mathrm{O}_{\mathrm{e}(\mathrm{Al})}$ & $-0.4910,-0.7848(-0.6379)$ & - \\
\hline $\mathrm{O}_{\mathrm{t}(\mathrm{Al})}$ & $-0.5553(-0.5553)$ & - \\
\hline $\mathrm{Al}$ & $-0.5307(-0.5307)$ & - \\
\hline $\mathrm{H}$ & $0.5754,0.5796(0.5775)$ & - \\
\hline
\end{tabular}

Table 4. Mulliken charges computed for $\left[\mathrm{a}-\mathrm{PW}_{11}\left\{\mathrm{Al}\left(\mathrm{OH}_{2}\right)\right\} \mathrm{O}_{39}\right]^{4-}$ and $\left[\mathrm{a}-\mathrm{PW}_{12} \mathrm{O}_{40}\right]^{3-}$. The terms $\mathrm{O}_{\mathrm{a}(\mathrm{M})}, \mathrm{O}_{\mathrm{c}(\mathrm{M})}, \mathrm{O}_{\mathrm{e}(\mathrm{M})}$, and $\mathrm{O}_{\mathrm{t}(\mathrm{M})}(\mathrm{M}=\mathrm{Al}$ and $\mathrm{W})$ are explained in Figs. 6 and 7. The average values are provided in parentheses. 


\subsection{Spectroscopic data for $\left[\left(n-\mathrm{C}_{4} \mathrm{H}_{9}\right)_{4} \mathrm{~N}\right]_{4}\left[\alpha-\mathrm{PW}_{11}\left\{\mathrm{Al}\left(\mathrm{OH}_{2}\right)\right\} \mathrm{O}_{39}\right]$}

The FTIR spectra measured as a $\mathrm{KBr}$ disk of $\left[\left(n-\mathrm{C}_{4} \mathrm{H}_{9}\right)_{4} \mathrm{~N}\right]_{4}\left[\mathrm{a}-\mathrm{PW}_{11}\left\{\mathrm{Al}\left(\mathrm{OH}_{2}\right)\right\} \mathrm{O}_{39}\right], \mathrm{K}_{7}[\mathrm{a}-$ $\left.\mathrm{PW}_{11} \mathrm{O}_{39}\right] \cdot 11 \mathrm{H}_{2} \mathrm{O}, \mathrm{Cs}_{7}\left[\mathrm{\gamma}-\mathrm{PW}_{10} \mathrm{O}_{36}\right] \cdot 19 \mathrm{H}_{2} \mathrm{O}$, and $\mathrm{Na}_{3}\left[\mathrm{a}-\mathrm{PW}_{12} \mathrm{O}_{40}\right] \cdot 16 \mathrm{H}_{2} \mathrm{O}$ are shown in Fig. 8. For
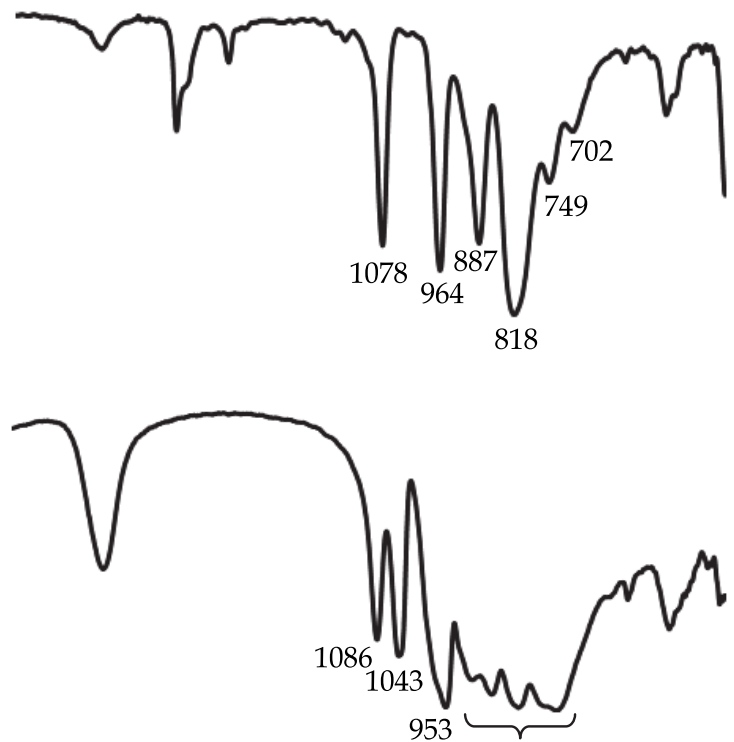

$903,862,810,734$

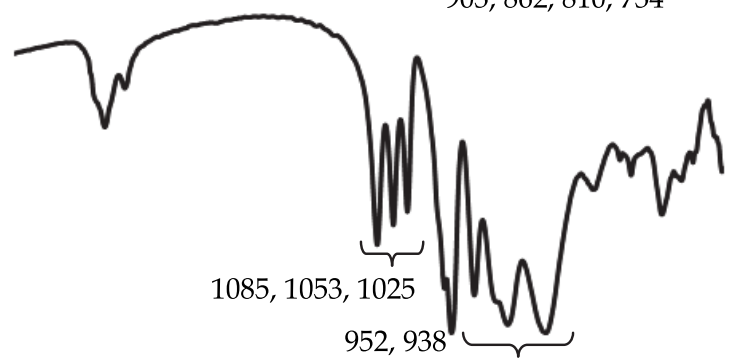

$893,827,751$

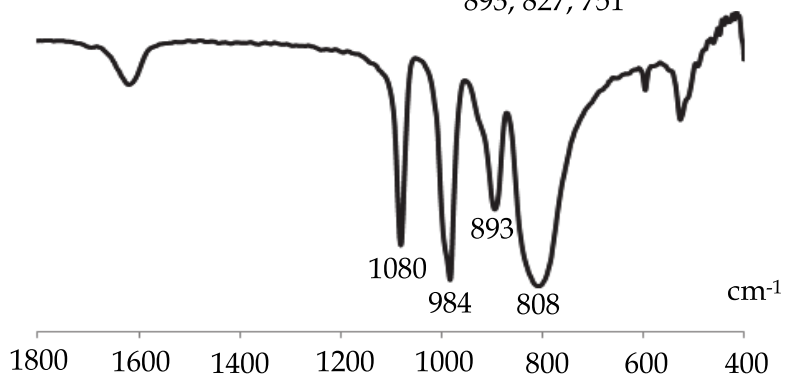

Fig. 8. FTIR spectra (as KBr disks) in the range of $1800-400 \mathrm{~cm}^{-1}$ for $\left[\left(n-\mathrm{C}_{4} \mathrm{H}_{9}\right)_{4} \mathrm{~N}\right]_{4}[\mathrm{a}-$ $\left.\mathrm{PW}_{11}\left\{\mathrm{Al}\left(\mathrm{OH}_{2}\right)\right\} \mathrm{O}_{39}\right]$ (top), $\mathrm{K}_{7}\left[\mathrm{a}-\mathrm{PW}_{11} \mathrm{O}_{39}\right] \cdot 11 \mathrm{H}_{2} \mathrm{O}$ (the second top), $\mathrm{Cs}_{7}\left[\gamma-\mathrm{PW}_{10} \mathrm{O}_{36}\right] \cdot 19 \mathrm{H}_{2} \mathrm{O}$ (the third top), and $\mathrm{Na}_{3}\left[\mathrm{a}-\mathrm{PW}_{12} \mathrm{O}_{40}\right] \cdot 16 \mathrm{H}_{2} \mathrm{O}$ (bottom) 
$\left[\left(n-\mathrm{C}_{4} \mathrm{H}_{9}\right)_{4} \mathrm{~N}\right]_{4}\left[\mathrm{a}-\mathrm{PW} \mathrm{P}_{11}\left\{\mathrm{Al}\left(\mathrm{OH}_{2}\right)\right\} \mathrm{O}_{39}\right]$, the P-O band was observed at $1078 \mathrm{~cm}^{-1}$, and the $\mathrm{W}-\mathrm{O}$ bands were observed at 964, 887, 818, 749, and $702 \mathrm{~cm}^{-1}$, these were different from those of $\mathrm{K}_{7}\left[\mathrm{a}-\mathrm{PW}_{11} \mathrm{O}_{39}\right] \cdot 11 \mathrm{H}_{2} \mathrm{O} \quad\left(1086,1043,953,903,862,810\right.$, and $\left.734 \mathrm{~cm}^{-1}\right)$ and $\mathrm{Cs}_{7}\left[\mathrm{\gamma}^{-}\right.$ $\left.\mathrm{PW}_{10} \mathrm{O}_{36}\right] \cdot 19 \mathrm{H}_{2} \mathrm{O}\left(1085,1053,1025,952,938,893,827\right.$, and $\left.751 \mathrm{~cm}^{-1}\right)$ (Rocchiccioli-Deltcheff et al., 1983; Thouvenot et al., 1984). This result suggested that the aluminum atom was coordinated into the vacant site in the polyoxometalate. It should be noted that the bands observed for $\left[\left(n-\mathrm{C}_{4} \mathrm{H}_{9}\right)_{4} \mathrm{~N}\right]_{4}\left[\mathrm{a}-\mathrm{PW}_{11}\left\{\mathrm{Al}\left(\mathrm{OH}_{2}\right) \mathrm{O}_{39}\right]\right.$ were significantly different from those of $\mathrm{Na}_{3}\left[\mathrm{a}-\mathrm{PW}_{12} \mathrm{O}_{40}\right] \cdot 16 \mathrm{H}_{2} \mathrm{O}\left(1080,984,893\right.$, and $\left.808 \mathrm{~cm}^{-1}\right)$. This was consistent with the results observed by X-ray crystallography and DFT calculations, as mentioned above.

The ${ }^{31} \mathrm{P}$ NMR spectrum of $\left[\left(n-\mathrm{C}_{4} \mathrm{H}_{9}\right)_{4} \mathrm{~N}\right]_{4}\left[\mathrm{a}-\mathrm{PW} \mathrm{P}_{11}\left\{\mathrm{Al}\left(\mathrm{OH}_{2}\right)\right\} \mathrm{O}_{39}\right]$ in acetonitrile- $d_{3}$ at $\sim 25^{\circ} \mathrm{C}$ was a clear single line spectrum at $-12.5 \mathrm{ppm}$ due to the internal phosphorus atom, thereby confirming the compound's purity and homogeneity, as shown in Fig. 9. The signal exhibited a shift from the signals of tetra- $n$-butylammonium salts of $\left[\mathrm{a}-\mathrm{PW}_{12} \mathrm{O}_{40}\right]^{3-}$ $(\delta-14.6)$ and $\left[a-\mathrm{PW}_{11} \mathrm{O}_{39}\right]^{7-}(\delta-12.0)$, suggesting the insertion of aluminum ion into the vacant site.

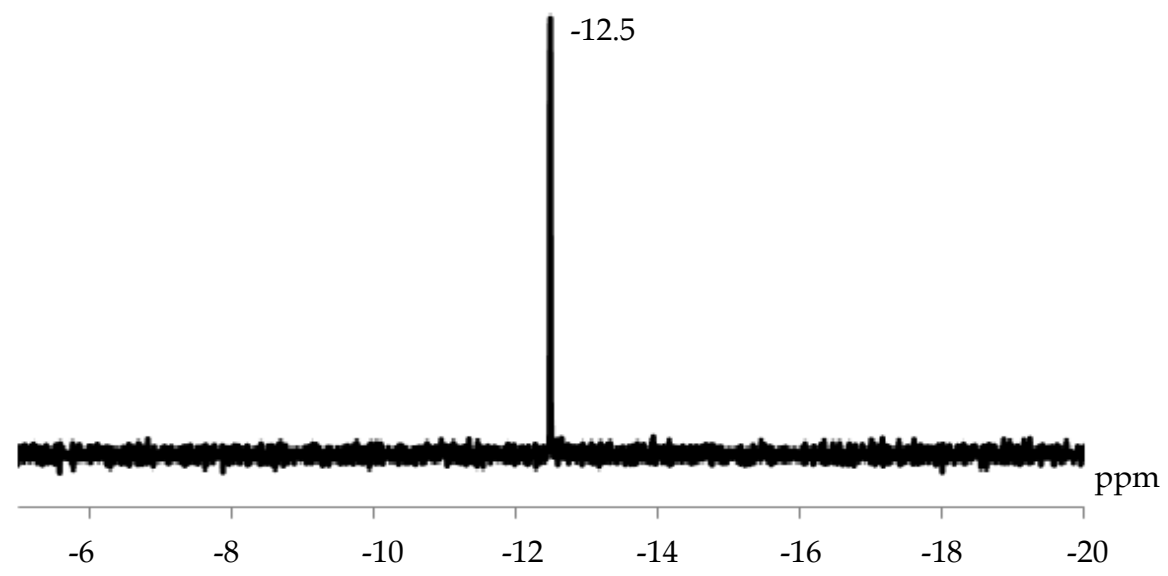

Fig. 9. ${ }^{31} \mathrm{P}$ NMR spectrum in acetonitrile- $d_{3}$ of $\left[\left(n-\mathrm{C}_{4} \mathrm{H}_{9}\right)_{4} \mathrm{~N}\right]_{4}\left[\mathrm{a}-\mathrm{PW} \mathrm{W}_{11}\left\{\mathrm{Al}\left(\mathrm{OH}_{2}\right)\right\} \mathrm{O}_{39}\right]$.

The ${ }^{27} \mathrm{Al}$ NMR spectrum (Fig. 10) of $\left[\left(n-\mathrm{C}_{4} \mathrm{H}_{9}\right)_{4} \mathrm{~N}\right]_{4}\left[\mathrm{a}-\mathrm{PW} \mathrm{P}_{11}\left\{\mathrm{Al}\left(\mathrm{OH}_{2}\right)\right\} \mathrm{O}_{39}\right]$ in acetonitrile- $d_{3}$ at $\sim 25{ }^{\circ} \mathrm{C}$ showed a broad signal at $16.1 \mathrm{ppm}$ due to the mono-aluminum-substituted site in [a$\left.\mathrm{PW}_{11}\left\{\mathrm{Al}\left(\mathrm{OH}_{2}\right)\right\} \mathrm{O}_{39}\right]^{4-}$.

The ${ }^{183} \mathrm{~W}$ NMR spectrum (Fig. 11) of $\left[\left(n-\mathrm{C}_{4} \mathrm{H}_{9}\right)_{4} \mathrm{~N}\right]_{4}\left[\mathrm{a}-\mathrm{PW} 11\left\{\mathrm{Al}\left(\mathrm{OH}_{2}\right)\right\} \mathrm{O}_{39}\right]$ in acetonitrile- $d_{3}$ at $\sim 25{ }^{\circ} \mathrm{C}$ was a six-line spectrum of $(\delta-56.2,-93.1,-108.6,-115.8,-118.5,-153.9)$ with 2:2:2:2:1:2 intensities, which were in accordance with the presence of eleven tungsten atoms with Cs symmetry. These spectral data were completely consistent with the X-ray structure and the optimized structure, suggesting that the solid structure was maintained in the solution. 


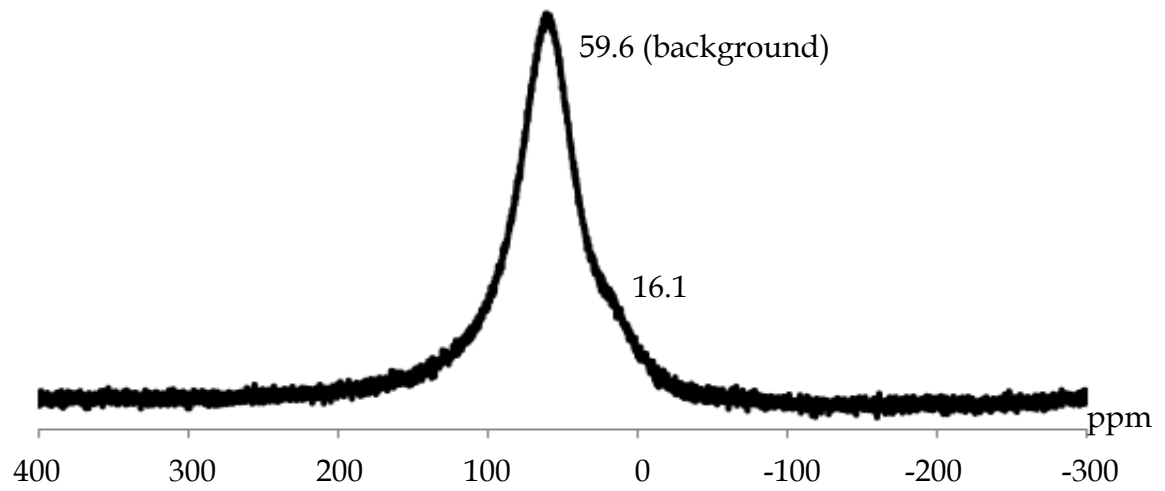

Fig. 10. ${ }^{27} \mathrm{Al} \mathrm{NMR}$ spectrum in acetonitrile- $d_{3}$ of $\left[\left(n-\mathrm{C}_{4} \mathrm{H}_{9}\right)_{4} \mathrm{~N}\right]_{4}\left[\mathrm{a}-\mathrm{PW} \mathrm{P}_{11}\left\{\mathrm{Al}\left(\mathrm{OH}_{2}\right)\right\} \mathrm{O}_{39}\right]$.

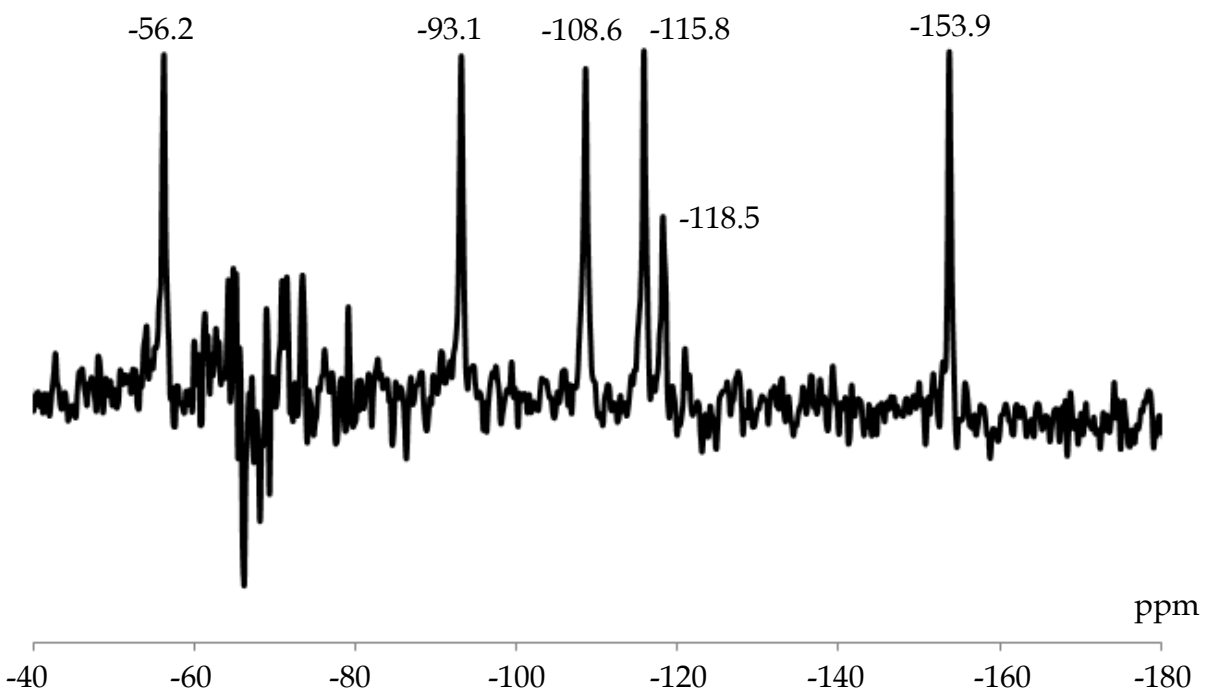

Fig. 11. ${ }^{183} \mathrm{~W}$ NMR spectrum in acetonitrile- $d_{3}$ of $\left[\left(n-\mathrm{C}_{4} \mathrm{H}_{9}\right)_{4} \mathrm{~N}\right]_{4}\left[\mathrm{a}-\mathrm{PW} \mathrm{P}_{11}\left\{\mathrm{Al}\left(\mathrm{OH}_{2}\right)\right\} \mathrm{O}_{39}\right]$.

\section{Conclusion}

The synthesis of a monomeric, mono-aluminum-substituted $\alpha$-Keggin polyoxometalate is described in this study. We successfully obtained single crystals of acetonitrile-soluble tetra$n$-butylammonium salt $\left[\left(n-\mathrm{C}_{4} \mathrm{H}_{9}\right)_{4} \mathrm{~N}\right]_{4}\left[\mathrm{a}-\mathrm{PW}_{11}\left\{\mathrm{Al}\left(\mathrm{OH}_{2}\right)\right\}_{39}\right]$ by reacting aluminum nitrate with a di-lacunary $\gamma$-Keggin phosphotungstate. The characterization of $\left[\left(n-\mathrm{C}_{4} \mathrm{H}_{9}\right)_{4} \mathrm{~N}\right]_{4}[\mathrm{a}-$ $\left.\mathrm{PW}_{11}\left\{\mathrm{Al}\left(\mathrm{OH}_{2}\right)\right\} \mathrm{O}_{39}\right]$ was accomplished by X-ray crystallography, elemental analysis, 
thermogravimetric/differential thermal analysis, Fourier transform infrared spectra, and solution ${ }^{31} \mathrm{P}, 27 \mathrm{Al}$, and ${ }^{183} \mathrm{~W}$ nuclear magnetic resonance spectroscopy. The single-crystal $\mathrm{X}$ ray structure analysis, revealed as $\left[\left(n-\mathrm{C}_{4} \mathrm{H}_{9}\right)_{4} \mathrm{~N}\right]_{4}\left[\mathrm{a}-\mathrm{PW}_{11}\left\{\mathrm{Al}\left(\mathrm{OH}_{2}\right)\right\} \mathrm{O}_{39}\right]$, was a monomeric, aKeggin structure, and the mono-aluminum-substituted site could not be identified due to the high symmetry in the product. In contrast, the DFT-optimized geometry of [a$\left.\mathrm{PW}_{11}\left\{\mathrm{Al}\left(\mathrm{OH}_{2}\right)\right\} \mathrm{O}_{39}\right]^{4-}$ showed that the mono-aluminum-substituted site was uniquely concave downward, which caused the extension of the P-O bond linkaged to the aluminum atom, whereas the Al-O bond linkaged to the phosphorus atom was shortened. This structural difference strongly influenced the bonding mode (bond lengths and bond angles) as determined by X-ray crystallography. In addition, the Mulliken charges clearly exhibited the effect caused by the insertion of aluminum atoms into the mono-vacant sites.

\section{Acknowledgment}

This work was supported by a Grant-in-Aid for Scientific Research on Innovative Areas (No. 21200055) of the Ministry of Education, Culture, Sports, Science and Technology, Japan. Y. Kataoka acknowledges the JSPS Research Fellowship for Young Scientist. Y. Kitagawa also has been supported by Grant-in-Aid for Scientific Research on Innovative Areas ("Coordination Programming" area 2170, No. 22108515) from the Ministry of Education, Culture, Sports, Science and Technology (MEXT). This research was partially carried out using equipment at the Center for Instrumental Analysis, Shizuoka University.

\section{Appendix}

Bond lengths $(\AA)$ of $\left[\left(n-\mathrm{C}_{4} \mathrm{H}_{9}\right)_{4} \mathrm{~N}\right]_{4}\left[\mathrm{a}-\mathrm{PW} \mathrm{W}_{11}\left\{\mathrm{Al}\left(\mathrm{OH}_{2}\right)\right\} \mathrm{O}_{39}\right]: \mathrm{W}(1)-\mathrm{O}(1) \quad 1.883(4) ; \mathrm{W}(1)-\mathrm{O}(1)^{1}$ 1.883(4); $\mathrm{W}(1)-\mathrm{O}(1)^{2}$ 1.883(4); $\mathrm{W}(1)-\mathrm{O}(1)^{3}$ 1.883(4); $\mathrm{W}(1)-\mathrm{O}(2)$ 2.465(5); $\mathrm{W}(1)-\mathrm{O}(2)^{4}$ 2.465(5); $\mathrm{W}(1)-\mathrm{O}(3)$ 1.667(4); $\mathrm{P}(1)-\mathrm{O}(2)$ 1.522(5); $\mathrm{P}(1)-\mathrm{O}(2)^{5}$ 1.522(5); $\mathrm{P}(1)-\mathrm{O}(2)^{6}$ 1.522(5); $\mathrm{P}(1)-\mathrm{O}(2)^{7}$ 1.522(5); $\mathrm{P}(1)-\mathrm{O}(2)^{4}$ 1.522(5); $\mathrm{P}(1)-\mathrm{O}(2)^{8}$ 1.522(5); $\mathrm{P}(1)-\mathrm{O}(2)^{9}$ 1.522(5); $\mathrm{P}(1)-\mathrm{O}(2)^{10} 1.522(5) ;$ $\mathrm{Al}(1)-\mathrm{O}(1)$ 1.883(4); $\mathrm{Al}(1)-\mathrm{O}(1)^{1} 1.883(4) ; \mathrm{Al}(1)-\mathrm{O}(1)^{2}$ 1.883(4); $\mathrm{Al}(1)-\mathrm{O}(1)^{3} 1.883(4) ; \mathrm{Al}(1)-\mathrm{O}(3)$ 1.667(4). Symmetry operators: (1) X,Z,Y (2) Z,Y,-X+1 (3) Z,-X+1,Y (4) $Y, Z,-X+1$ (5) $Y, Z, X(6)$ $Z, X, Y(7) X, Y,-Z+1(8) Z, X,-Y+1(9)-Z+1, X,-Y+1$ (10) -Y+1,-Z+1,-X+1.

Bond angles $\left({ }^{\circ}\right)$ of $\left[\left(n-\mathrm{C}_{4} \mathrm{H}_{9}\right)_{4} \mathrm{~N}\right]_{4}\left[\mathrm{a}-\mathrm{PW}_{11}\left\{\mathrm{Al}\left(\mathrm{OH}_{2}\right)\right\} \mathrm{O}_{39}\right]$ : $\mathrm{O}(1)-\mathrm{W}(1)-\mathrm{O}(1)^{1} 87.5(2) ; \mathrm{O}(1)-\mathrm{W}(1)-$ $\mathrm{O}(1)^{2} \quad 87.08(18) ; \quad \mathrm{O}(1)-\mathrm{W}(1)-\mathrm{O}(1)^{3} \quad$ 154.8(2); $\mathrm{O}(1)-\mathrm{W}(1)-\mathrm{O}(2) \quad$ 63.32(19); $\mathrm{O}(1)-\mathrm{W}(1)-\mathrm{O}(2)^{4}$ 92.40(18); $\mathrm{O}(1)-\mathrm{W}(1)-\mathrm{O}(3)$ 102.58(17); $\mathrm{O}(1)^{1}-\mathrm{W}(1)-\mathrm{O}(1)^{2}$ 154.8(2) $\mathrm{O}(1)^{1-\mathrm{W}}(1)-\mathrm{O}(1)^{3}$ 87.08(18); $\mathrm{O}(1)^{1}-\mathrm{W}(1)-\mathrm{O}(2) \quad 63.32(19) ; \mathrm{O}(1)^{1}-\mathrm{W}(1)-\mathrm{O}(2)^{4} \quad 92.40(18) ; \mathrm{O}(1)^{1}-\mathrm{W}(1)-\mathrm{O}(3)$ 102.58(17); $\mathrm{O}(1)^{2}-$ $\mathrm{W}(1)-\mathrm{O}(1)^{3}$ 87.5(2); O(1)2-W(1)-O(2) 92.40(18); O(1)2-W(1)-O(2) $63.32(19) ; \mathrm{O}(1)^{2}-\mathrm{W}(1)-\mathrm{O}(3)$ 102.58(17); $\mathrm{O}(1)^{3}-\mathrm{W}(1)-\mathrm{O}(2)$ 92.40(18); O(1)3-W(1)-O(2) ${ }^{4}$ 63.32(19); $\mathrm{O}(1)^{3}-\mathrm{W}(1)-\mathrm{O}(3)$ 102.58(17); $\mathrm{O}(2)-\mathrm{W}(1)-\mathrm{O}(2)^{4} 41.76(15) ; \mathrm{O}(2)-\mathrm{W}(1)-\mathrm{O}(3)$ 159.12(11); $\mathrm{O}(2)^{4}-\mathrm{W}(1)-\mathrm{O}(3)$ 159.12(11); $\mathrm{O}(2)-\mathrm{P}(1)-$ $\mathrm{O}(2)^{5}$ 109.5(3); $\mathrm{O}(2)-\mathrm{P}(1)-\mathrm{O}(2)^{6}$ 109.5(3); O(2)-P(1)-O(2) 7 70.5(3); O(2)-P(1)-O(2) 4 70.5(3); $\mathrm{O}(2)-$ $\mathrm{P}(1)-\mathrm{O}(2)^{8} \quad 180.0(4) ; \quad \mathrm{O}(2)-\mathrm{P}(1)-\mathrm{O}(2)^{9} \quad 109.5(3) ; \quad \mathrm{O}(2)-\mathrm{P}(1)-\mathrm{O}(2)^{10} \quad 70.5(3) ; \quad \mathrm{O}(2)^{5}-\mathrm{P}(1)-\mathrm{O}(2)^{6}$ 109.5(3); $\mathrm{O}(2)^{5}-\mathrm{P}(1)-\mathrm{O}(2)^{7} 70.5(3) ; \mathrm{O}(2)^{5}-\mathrm{P}(1)-\mathrm{O}(2)^{4} 70.5(3) ; \mathrm{O}(2)^{5}-\mathrm{P}(1)-\mathrm{O}(2)^{8} 70.5(3) ; \mathrm{O}(2)^{5}-\mathrm{P}(1)-$ $\mathrm{O}(2)^{9}$ 109.5(3); $\mathrm{O}(2)^{5}-\mathrm{P}(1)-\mathrm{O}(2)^{10} 180.0(4) ; \mathrm{O}(2)^{6}-\mathrm{P}(1)-\mathrm{O}(2)^{7}$ 180.0(4); $\mathrm{O}(2)^{6}-\mathrm{P}(1)-\mathrm{O}(2)^{4}$ 70.5(3); $\mathrm{O}(2)^{6}-\mathrm{P}(1)-\mathrm{O}(2)^{8}$ 70.5(3); $\mathrm{O}(2)^{6}-\mathrm{P}(1)-\mathrm{O}(2)^{9}$ 109.5(3); $\mathrm{O}(2)^{6}-\mathrm{P}(1)-\mathrm{O}(2)^{10} 70.5(3) ; \mathrm{O}(2)^{7}-\mathrm{P}(1)-\mathrm{O}(2)^{4}$ 109.5(3); $\mathrm{O}(2)^{7}-\mathrm{P}(1)-\mathrm{O}(2)^{8}$ 109.5(3); $\mathrm{O}(2)^{7}-\mathrm{P}(1)-\mathrm{O}(2)^{9} 70.5(3) ; \mathrm{O}(2)^{7}-\mathrm{P}(1)-\mathrm{O}(2)^{10} 109.5(3) ; \mathrm{O}(2)^{4-}$ $\mathrm{P}(1)-\mathrm{O}(2)^{8}$ 109.5(3); $\mathrm{O}(2)^{4}-\mathrm{P}(1)-\mathrm{O}(2)^{9} \quad 180.0(4) ; \quad \mathrm{O}(2)^{4}-\mathrm{P}(1)-\mathrm{O}(2)^{10} \quad 109.5(3) ; \mathrm{O}(2)^{8}-\mathrm{P}(1)-\mathrm{O}(2)^{9}$ 70.5(3); $\mathrm{O}(2)^{8}-\mathrm{P}(1)-\mathrm{O}(2)^{10}$ 109.5(3); $\mathrm{O}(2)^{9}-\mathrm{P}(1)-\mathrm{O}(2)^{10}$ 70.5(3); O(1)-Al(1)-O(1) 1 87.5(2); $\mathrm{O}(1)-$ 
$\mathrm{Al}(1)-\mathrm{O}(1)^{2}$ 87.08(18); O(1)-Al(1)-O(1) 3 154.8(2); $\mathrm{O}(1)-\mathrm{Al}(1)-\mathrm{O}(3)$ 102.58(17); $\mathrm{O}(1)^{1}-\mathrm{Al}(1)-\mathrm{O}(1)^{2}$ 154.8(2); $\mathrm{O}(1)^{1}-\mathrm{Al}(1)-\mathrm{O}(1)^{3}$ 87.08(18); $\mathrm{O}(1)^{1}-\mathrm{Al}(1)-\mathrm{O}(3)$ 102.58(17); $\mathrm{O}(1)^{2}-\mathrm{Al}(1)-\mathrm{O}(1)^{3}$ 87.5(2); $\mathrm{O}(1)^{2}-\mathrm{Al}(1)-\mathrm{O}(3) \quad 102.58(17) ; \mathrm{O}(1)^{3}-\mathrm{Al}(1)-\mathrm{O}(3)$ 102.58(17); $\mathrm{W}(1)-\mathrm{O}(1)-\mathrm{W}(1)^{11}$ 140.7(3); W(1)$\mathrm{O}(1)-\mathrm{Al}(1)^{11}$ 140.7(3); W(1) ${ }^{11}-\mathrm{O}(1)-\mathrm{Al}(1)$ 140.7(3); $\mathrm{Al}(1)-\mathrm{O}(1)-\mathrm{Al}(1)^{11} 140.7(3) ; \mathrm{W}(1)-\mathrm{O}(2)-\mathrm{W}(1)^{11}$ 91.97(16); $\mathrm{W}(1)-\mathrm{O}(2)-\mathrm{W}(1)^{12}$ 91.97(16); $\mathrm{W}(1)-\mathrm{O}(2)-\mathrm{P}(1)$ 123.9(3); $\mathrm{W}(1)-\mathrm{O}(2)-\mathrm{O}(2)^{7}$ 131.4(3); $\mathrm{W}(1)-\mathrm{O}(2)-\mathrm{O}(2)^{4}$ 69.1(3); W(1)-O(2)-O(2) ${ }^{10} 131.4(3) ; \mathrm{W}(1)^{11}-\mathrm{O}(2)-\mathrm{W}(1)^{12}$ 91.97(16); W(1)11-O(2)$\mathrm{P}(1) \quad$ 123.9(3); $\mathrm{W}(1)^{11}-\mathrm{O}(2)-\mathrm{O}(2)^{7} \quad 69.1(3) \quad \mathrm{W}(1)^{11}-\mathrm{O}(2)-\mathrm{O}(2)^{4} \quad 131.4(3) ; \mathrm{W}(1)^{11}-\mathrm{O}(2)-\mathrm{O}(2)^{10}$ 131.4(3); $\mathrm{W}(1)^{12}-\mathrm{O}(2)-\mathrm{P}(1)$ 123.9(3); $\mathrm{W}(1)^{12}-\mathrm{O}(2)-\mathrm{O}(2)^{7} \quad 131.4(3) ; \mathrm{W}(1)^{12}-\mathrm{O}(2)-\mathrm{O}(2)^{4}$ 131.4(3); $\mathrm{W}(1)^{12}-\mathrm{O}(2)-\mathrm{O}(2)^{10}$ 69.1(3); $\mathrm{P}(1)-\mathrm{O}(2)-\mathrm{O}(2)^{7}$ 54.7(3); $\mathrm{P}(1)-\mathrm{O}(2)-\mathrm{O}(2)^{4}$ 54.7(3); $\mathrm{P}(1)-\mathrm{O}(2)-\mathrm{O}(2)^{10}$ 54.7(3); $\quad \mathrm{O}(2)^{7}-\mathrm{O}(2)-\mathrm{O}(2)^{4} \quad 90.0(3) ; \quad \mathrm{O}(2)^{7}-\mathrm{O}(2)-\mathrm{O}(2)^{10} \quad 90.0(3) ; \quad \mathrm{O}(2)^{4}-\mathrm{O}(2)-\mathrm{O}(2)^{10} \quad 90.0(3)$. Symmetry operators: (1) X,Z,Y (2) Z,Y,-X+1 (3) Z,-X+1,Y (4) $Y, Z,-X+1$ (5) $Y, Z, X(6) Z, X, Y(7)$ $X, Y,-Z+1$ (8) $Z, X,-Y+1$ (9) -Z+1,X,-Y+1 (10) -Y+1,-Z+1,-X+1 (11) - $Y+1, Z,-X+1$ (12) -Z+1,-X+1,Y.

\section{References}

Akitt, J. W. (1988). Multinuclear Studies of Aluminum Compounds. Prog. Nucl. Magn. Res. Spectr.,Vol.21, No.1-2, pp. 1-149

Baes, C. F. Jr. \& Mesmer, R. E. (1976). The Hydrolysis of Cations, pp. 112-123, John Wiley, New York, 1976

Busbongthong, S. \& Ozeki, T. (2009). Structural Relationships among Methyl-, Dimethyl-, and Trimethylammonium Phosphdodecatungstates. Bull. Chem. Soc. Jpn., Vol.82, No.11, pp. 1393-1397

Contant, R. (1987). Relation between Tungstophosphates Related to the Phosphorus Tungsten Oxide Anion $\left(\mathrm{PW}_{12} \mathrm{O}_{40} 0^{3-}\right)$. Synthesis and Properties of a New Lacunary Potassium Polytungstophosphate $\left(\mathrm{K}_{10} \mathrm{P}_{2} \mathrm{~W}_{20} \mathrm{O}_{70} \cdot 24 \mathrm{H}_{2} \mathrm{O}\right)$. Can. J. Chem., Vol.65, No.3, pp. 568-573

Cotton, F. A. \& Wilkinson, G. (1988). Advanced Inorganic Chemistry, Fifth Edition, John Wiley \& Sons, New York

Djurdjevic P.; Jelic, R. \& Dzajevic, D. (2000). The Effect of Surface Active Substances on Hydrolysis of Aluminum(III) Ion. Main Metal Chemistry, Vol.23, No.8, pp. 409-421

Domaille, P. J. (1990). Vanadium(V) Substituted Dodecatungstophosphates. Inorg. Synth., Vol.27, pp. 96-104

Frisch, M. J.; Trucks, G. W.; Schlegel, H. B.; Scuseria, G. E.; Robb, M. A.; Cheeseman, J. R.; Scalmani, G.; Barone, V.; Mennucci, B.; Petersson, G. A.; Nakatsuji, H.; Caricato, M.; Li, X.; Hratchian, H. P.; Izmaylov, A. F.; Bloino, J.; Zheng, G.; Sonnenberg, J. L.; Hada, M.; Ehara, M.; Toyota, K.; Fukuda, R.; Hasegawa, J.; Ishida, M.; Nakajima, T.; Honda, Y.; Kitao, O.; Nakai, H.; Vreven, T.; Montgomery, Jr., J. A.; Peralta, J. E.; Ogliaro, F.; Bearpark, M.; Heyd, J. J.; Brothers, E.; Kudin, K. N.; Staroverov, V. N.; Kobayashi, R.; Normand, J.; Raghavachari, K.; Rendell, A.; Burant, J. C.; Iyengar, S. S.; Tomasi, J.; Cossi, M.; Rega, N.; Millam, N. J.; Klene, M.; Knox, J. E.; Cross, J. B.; Bakken, V.; Adamo, C.; Jaramillo, J.; Gomperts, R.; Stratmann, R. E.; Yazyev, O.; Austin, A. J.; Cammi, R.; Pomelli, C.; Ochterski, J. W.; Martin, R. L.; Morokuma, K.; Zakrzewski, V. G.; Voth, G. A.; Salvador, P.; Dannenberg, J. J.; Dapprich, S.; Daniels, A. D.; Farkas, Ö.; Foresman, J. B.; Ortiz, J. V.; Cioslowski, J. \& Fox, D. J. (2009). Gaussian 09, Revision B.1, Gaussian, Inc., Wallingford CT

Fukaya, K.; Srifa, A.; Ishikawa, E. \& Naruke, H. (2010). Synthesis and Structural Characterization of Polyoxometalates Incorporating with Anilinium Cations and Facile Preparation of Hybrid Film. J. Mol. Struc. Vol.979, pp. 221-226 
Hou, Y.; Fang, X. \& Hill, C. L. (2007). Breaking Symmetry: Spontaneous Resolution of a Polyoxometalate. Chem. Eur. J. Vol.13, pp. 9442-9447

Kato, C. N.; Hara, K.; Kato, M.; Amano, H.; Sato, K.; Kataoka, Y. \& Mori, W. (2010). EDTAReduction of Water to Molecular Hydrogen Catalyzed by Visible-Light-Response $\mathrm{TiO}_{2}$-Based Materials Sensitized by Dawson- and Keggin-Type Rhenium(V)Containing Polyoxotungstates. Materials, Vol.3, pp. 897-917

Kato, C. N.; Katayama, Y.; Nagami, M.; Kato, M. \& Yamasaki, M. (2010). A Sandwich-type Aluminium Complex Composed of Tri-lacunary Keggin-type Polyoxotungstate: Synthesis and X-Ray Crystal Structure of $\left[\left(\mathrm{A}-\mathrm{PW}_{9} \mathrm{O}_{34}\right)_{2}\left\{\mathrm{~W}(\mathrm{OH})\left(\mathrm{OH}_{2}\right)\right\}-\right.$ $\left.\left\{\mathrm{Al}(\mathrm{OH})\left(\mathrm{OH}_{2}\right)\right\}\left\{\mathrm{Al}(\mu-\mathrm{OH})\left(\mathrm{OH}_{2}\right)_{2}\right\}_{2}\right]^{7-}$. Dalton Trans., Vol.39, pp. 11469-11474

Kikukawa, Y.; Yamaguchi, S.; Nakagawa, Y.; Uehara, K.; Uchida, S.; Yamaguchi, K. \& Mizuno, N. (2008). Synthesis of a Dialuminum-Substituted Silicotungstate and the Diasteroselective Cyclization of Citronellal Derivatives. J. Am. Chem. Soc., Vol.130, No.47, 15872-15878

Knoth, W. H.; Domaille, P. J. \& Roe, D. C. (1983). Halometal Derivatives of $\mathrm{W}_{12} \mathrm{PO}_{40^{3-}}$ and Related ${ }^{183}$ W NMR Studies. Inorg. Chem. Vol.22, 198-201

Knoth, W. H. \& Harlow, R. L. (1981). New Tungstophosphates: $\mathrm{Cs}_{6} \mathrm{~W}_{5} \mathrm{P}_{2} \mathrm{O}_{23}, \mathrm{Cs}_{7} \mathrm{~W}_{10} \mathrm{PO}_{36}$ and $\mathrm{Cs}_{7} \mathrm{Na}_{2} \mathrm{~W}_{10} \mathrm{PO}_{37}$. J. Am. Chem. Soc., Vol.103. No.7, pp. 1865-1867

Lin, Y.; Weakley, T. J. R.; Rapko, B. \& Finke, R. G. (1993). Polyoxoanions Derived from Tungstosilicatie $\left(\mathrm{A}-\beta-\mathrm{SiW}_{9} \mathrm{O}_{34}{ }^{10-}\right)$ : Synthesis, Single-crystal Structural Determination, and Solution Structural Characterization by Tungsten-183 NMR and IR of Titanotungstosilicate $\left(\mathrm{A}-\beta-\mathrm{Si}_{2} \mathrm{~W}_{18} \mathrm{Ti}_{6} \mathrm{O}_{77^{14}}\right)$. Inorg. Chem., Vol.32, No.23, pp. 5095-5101

Maestre, J. M.; Lopez, X.; Bo, C.; Poblet, J.-M. \& Casan-Pastor N. (2001). Electronic and Magnetic Properties of $\alpha$-Keggin Anions: A DFT Study of $\left[\mathrm{XM}_{12} \mathrm{O}_{40}\right]^{\mathrm{n}-},(\mathrm{M}=\mathrm{W}$, Mo; $\left.\mathrm{X}=\mathrm{Al}{ }^{\mathrm{III}}, \mathrm{Si}{ }^{\mathrm{VI}}, \mathrm{PV}, \mathrm{Fe}^{\mathrm{III}}, \mathrm{Co}^{\mathrm{II}}, \mathrm{Co}{ }^{\mathrm{III}}\right)$ and $\left[\mathrm{SiM}_{11} \mathrm{VO}_{40}\right]^{\mathrm{m}-}(\mathrm{M}=\mathrm{Mo}$ and $\mathrm{W}) . J$. Am. Chem. Soc., Vol.123, pp. 3749-3758

Neiwert, W. A.; Cowan, J. J.; Hardcastle, K. I.; Hill, C. L. \& Weinstock, I. A. (2002). Stability and Structure in $\alpha$ - and $\beta$-Keggin Heteropolytungstates, $\left[\mathrm{X}^{\mathrm{n}+} \mathrm{W}_{12} \mathrm{O}_{40}\right]^{(8-\mathrm{n})-}, \mathrm{X}=p$ Block Cation. Inorg. Chem., Vol.41, 6950-6952

Nomiya, K.; Takahashi, M.; Ohsawa, K. \& Widegren, J. A. (2001). Synthesis and Characterization of Tri-titanium(IV)-1,2,3-substituted a-Keggin Polyoxotungstates with Heteroatoms $\mathrm{P}$ and Si. Crystal Structure of the Dimeric, Ti-O-Ti Bridged Anhydride Form $\mathrm{K}_{10} \mathrm{H}_{2}\left[\mathrm{a}, \mathrm{a}-\mathrm{P}_{2} \mathrm{~W}_{18} \mathrm{Ti}_{6} \mathrm{O}_{77}\right] \cdot 17 \mathrm{H}_{2} \mathrm{O}$ and Confirmation of Dimeric Forms in Aqueous Solution by Ultracentrifugation Molecular Weight Measurements. J. Chem. Soc., Dalton Trans. No.19, pp. 2872-2878

Nomiya, K.; Takahashi, M. Widegren, J. A.; Aizawa, T.; Sakai, Y. \& Kasuga, N. C. (2002). Synthesis and $\mathrm{pH}-$ Variable Ultracentrifugation Molecular Weight Measurements of the Dimeric, Ti-O-Ti Bridged Anhydride Form of a Novel Di-TiIV-substituted aKeggin Polyoxotungstate. Molecular Structure of the $\left[\left(\mathrm{a}-1,2-\mathrm{PW}_{10} \mathrm{Ti}_{2} \mathrm{O}_{39}\right)_{2}\right]^{10-}$ Polyoxoanion. J. Chem. Soc., Dalton Trans. No.19, pp. 3679-3685

Ortéga, F.; Pope, M. T. \& Evans, H.T., Jr. (1997). Tungstorhenate Heteropolyanions. 2. Synthesis and Characterization of Enneatungstorhebates(V), -(VI) and -(VII). Inorg. Chem., Vol.36, No.10, pp. 2166-2169

Orvig, C. (1993). The Aqueous Coordination Chemistry of Aluminum In: Coordination Chemistry of Aluminum, G.H. Robinson, (Ed.), 85-121, VCH, Weinheim

Patel, K.; Shringarpure, P. \& Patel, A. (2011). One-step Synthesis of a Keggin-type Manganese(II)-substitited Phosphotungstate: Structrural and Spectroscopic 
Characterization and Non-solvent Liquid Phase Oxidation of Styrene. Transition Met. Chem., Vol.36, pp. 171-177

Pope, M. T. (1983). Heteropoly and Isopoly Oxometalates, Springer-Verlag, Berlin

Pope, M. T. \& Müller, A. (1991). Chemistry of Polyoxometallates. Actual Variation on an Old Theme with Interdisciplinary References. Angew. Chem. Int. Ed. Engl., Vol.30, No.1, pp. 34-48

Pope, M. T. \& Müller, A. (Eds.), (1994). Polyoxometalates: From Platonic Solids to Anti-Retroviral Activity, Kluwer Academic Publishers, Dordrecht, The Netherlands

Reinoso, S.; Vitoria, P.; Felices, L. S.; Lezama, L. \& Gutiérrez-Zorrilla, J. M. (2006). Analysis of Weak Interactions in the Crystal Packing of Inorganic Metalorganic Hybrids Based on Keggin Polyoxometalates and Dinuclear Copper(II)-Acetate Complexes. Inorg. Chem., Vol.45, pp. 108-118

Rocchiccioli-Deltcheff, C.; Fournier, M.; Franck, R. \& Thouvenot, R. (1983). Vibrational Investigations of Polyoxometalates. 2. Evidence for Anion-Anion Interactions in Molybdenum(VI) and Tungsten(VI) Compounds Related to the Keggin Structure. Inorg. Chem., Vol.22, pp. 207-216

Rosenheim, A. \& Jaenicke, J. Z. (1917). Iso- and Heteropoly Acids. XV. Heteropoly tungstates and Some Heteropoly Molybdates. Anorg. Allg. Chem., Vol.101, pp. 235275

Shannon, R. D. (1976). Revised Effective Ionic Radii and Systematic Studies of Interatomic Distances in Halides and Chalcogenides. Acta Crystallogr., Sect. A, Vol.A32, pp. 751767

Sheldrick, G. M. (2008). A Short History of SHELX. Acta Crystallogr., Sect. A, Vol.A46, No.1, pp. $112-122$

Spek, A. L. (2009). Structure Validation in Chemical Crystallography. Acta Crystallogr., Sect. D, Vol.D65, No.2, pp. 148-155

Thouvenot, R.; Fournier, M.; Franck, R. \& Rocchiccioli-Deltcheff, C. (1984). Vibrational Investigations of Polyoxometalates. 3. Isomerism in Molybdenum(VI) and Tungsten(VI) Compounds Related to the Keggin Structure. Inorg. Chem., Vol.23, pp. 598-605

Weakley, T. J. R. (1987). Crystal Structure of Cesium Aquanickelo(II)undecatungstophsphate Dihydrate. J. Cryst. Spectro. Res., Vol.17, No.3, pp. 383-391

Weakley, T. J. R. \& Finke, R. G. (1990). Single-crystal X-Ray Structures of the Polyoxotungstate Salts $\mathrm{K}_{8.3} \mathrm{Na}_{1.7}\left[\mathrm{Cu}_{4}\left(\mathrm{H}_{2} \mathrm{O}\right)_{2}\left(\mathrm{PW}_{9} \mathrm{O}_{34}\right)_{2}\right] \cdot 24 \mathrm{H}_{2} \mathrm{O}$ and $\mathrm{Na}_{14} \mathrm{Cu}_{2}\left[\mathrm{Cu}_{4}-\right.$ $\left.\left(\mathrm{H}_{2} \mathrm{O}\right)_{2}\left(\mathrm{P}_{2} \mathrm{~W}_{15} \mathrm{O}_{56}\right)_{2}\right] \cdot 53 \mathrm{H}_{2} \mathrm{O}$. Inorg. Chem., Vol.29, No.6, pp. 1235-1241

Weiner, H.; Aiken III, J. D. \& Finke, R. G. (1996). Polyoxometalate Catalyst Precursors. Improved Synthesis, $\mathrm{H}^{+}$-Titration Procedure, and Evidence for ${ }^{31} \mathrm{P}$ NMR as a Highly Sensitive Support-Site Indicator for the Prototype PolyoxoanionOrganometallic-support System $\left[\left(n-\mathrm{C}_{4} \mathrm{H}_{9}\right)_{4} \mathrm{~N}_{9} \mathrm{P}_{2} \mathrm{~W}_{15} \mathrm{Nb}_{3} \mathrm{O}_{62}\right.$. Inorg. Chem., Vol.35, pp. 7905-7913

Yang, Q. H.; Zhou, D. F.; Dai, H. C.; Liu, J. F.; Xing, Y.; Lin, Y. H. \& Jia, H. Q. (1997). Synthesis, Structure and Properties of Undecatungstozincate Containing 3A Elements. Polyhedron, Vol.16, No.23, 3985-3989 


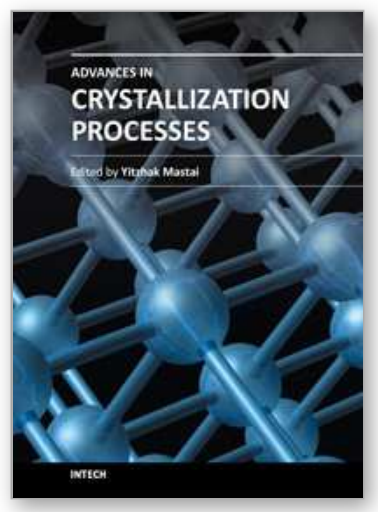

\section{Advances in Crystallization Processes}

Edited by Dr. Yitzhak Mastai

ISBN 978-953-51-0581-7

Hard cover, 648 pages

Publisher InTech

Published online 27, April, 2012

Published in print edition April, 2012

Crystallization is used at some stage in nearly all process industries as a method of production, purification or recovery of solid materials. In recent years, a number of new applications have also come to rely on crystallization processes such as the crystallization of nano and amorphous materials. The articles for this book have been contributed by the most respected researchers in this area and cover the frontier areas of research and developments in crystallization processes. Divided into five parts this book provides the latest research developments in many aspects of crystallization including: chiral crystallization, crystallization of nanomaterials and the crystallization of amorphous and glassy materials. This book is of interest to both fundamental research and also to practicing scientists and will prove invaluable to all chemical engineers and industrial chemists in the process industries as well as crystallization workers and students in industry and academia.

\section{How to reference}

In order to correctly reference this scholarly work, feel free to copy and paste the following:

Chika Nozaki Kato, Yuki Makino, Mikio Yamasaki, Yusuke Kataoka, Yasutaka Kitagawa and Mitsutaka Okumura (2012). Synthesis and X-Ray Crystal Structure of $\alpha$-Keggin-Type Aluminum-Substituted Polyoxotungstate, Advances in Crystallization Processes, Dr. Yitzhak Mastai (Ed.), ISBN: 978-953-51-0581-7, InTech, Available from: http://www.intechopen.com/books/advances-in-crystallization-processes/synthesisand-x-ray-crystal-structure-of-alpha-keggin-type-mono-aluminum-substituted-polyoxotungstat

\section{INTECH}

open science | open minds

\section{InTech Europe}

University Campus STeP Ri

Slavka Krautzeka 83/A

51000 Rijeka, Croatia

Phone: +385 (51) 770447

Fax: +385 (51) 686166

www.intechopen.com

\section{InTech China}

Unit 405, Office Block, Hotel Equatorial Shanghai

No.65, Yan An Road (West), Shanghai, 200040, China

中国上海市延安西路65号上海国际贵都大饭店办公楼 405 单元

Phone: +86-21-62489820

Fax: $+86-21-62489821$ 
(C) 2012 The Author(s). Licensee IntechOpen. This is an open access article distributed under the terms of the Creative Commons Attribution 3.0 License, which permits unrestricted use, distribution, and reproduction in any medium, provided the original work is properly cited. 